Atmos. Chem. Phys. Discuss., 9, 3007-3040, 2009

www.atmos-chem-phys-discuss.net/9/3007/2009/

(C) Author(s) 2009. This work is distributed under

the Creative Commons Attribution 3.0 License.

This discussion paper is/has been under review for the journal Atmospheric Chemistry and Physics $(A C P)$. Please refer to the corresponding final paper in $A C P$ if available.

\title{
2003 megafires in Australia: impact on tropospheric ozone and aerosols
}

\section{G. Guerova and N. Jones}

Centre for Atmospheric Chemistry, Univ. of Wollongong, Wollongong, NSW 2522, Australia

Received: 8 December 2008 - Accepted: 23 December 2008 - Published: 29 January 2009

Correspondence to: G. Guerova (guergana @uow.edu.au)

Published by Copernicus Publications on behalf of the European Geosciences Union.

Title Page

Abstract

Introduction

Conclusions

References

Tables

Figures

14

$>1$

4

Back

Close

Full Screen / Esc

Printer-friendly Version

Interactive Discussion 


\section{Abstract}

2003 was a record year for wildfires worldwide. Severe forest fires killed four people, displaced 20500 others and burnt 260000 ha in South-East Australia in January 2003. The uncontrolled fires ignited in early January 2003 as a result of a prolonged

5 El Niño drought in South-East Australia. Severe weather conditions resulted in a fast spread of the fires and poor air quality in a region where $70 \%$ of the population of Australia lives. We use state-of-art global chemistry and transport model GEOS-Chem in conjunction with ground- and space-based observations to study the ozone $\left(\mathrm{O}_{3}\right)$ and aerosol enhancement due to fires. Firstly, the monthly mean surface $\mathrm{O}_{3}$ and Aerosol Optical Depth (AOD) in January 2003 are compared to January 2004 and, secondly, from sensitivity model simulations, four episodes are isolated and an attempt is made to quantify the contribution of the fires to air quality in south and South-East Australia.

In January 2003 the observed monthly mean afternoon surface $\mathrm{O}_{3}$ in Victoria (VIC) and South Australia (SA) reached $27.5 \mathrm{ppb}$, which is $6.5 \mathrm{ppb}$ (i.e. $30 \%$ ) higher than

15 in 2004 . The simulated $\mathrm{O}_{3}$ is $29.5 \mathrm{ppb}$, which is $10 \mathrm{ppb}$ higher than in 2004 . While the model tends to overestimate the observed peak $\mathrm{O}_{3}$, it exhibits very good skill in reproducing the $\mathrm{O}_{3}$ temporal variability in January 2003 with a correlation of 0.83 . In $\mathrm{VIC}$, the air quality 4-h ozone $\left(\mathrm{O}_{3}\right)$ standard exceedences are reported on 17, 24 and 25 January. On 12, 17, 24-25 and 29 January 2003, the observed $\mathrm{O}_{3}$ peaks above $40 \mathrm{ppb}$ and the simulated fire contribution is higher than $10 \mathrm{ppb}$. During these 4 episodes, the range of observed $\mathrm{O}_{3}$ enhancement due to fires is $20-35 \mathrm{ppb}$, which is a factor of 3 to 5 higher than the monthly mean. The simulated fire $\mathrm{O}_{3}$ enhancement is in the range 15-50 ppb with a factor of 1.5 to 5 higher than the monthly mean. During two episodes, a well-formed surface wind channel stretches across the Tasman Sea facilitating the long range transport to New Zealand contributing to a $10 \%$ increase of surface $\mathrm{O}_{3}$.

During the four episodes in January 2003, the observed AOD was up to a factor of five higher that the monthly mean AOD. The simulated and observed AODs agree on the spatial structure. Despite the model tendency to underestimate the AOD, it proves

2003 megafires in Australia

G. Guerova and N. Jones

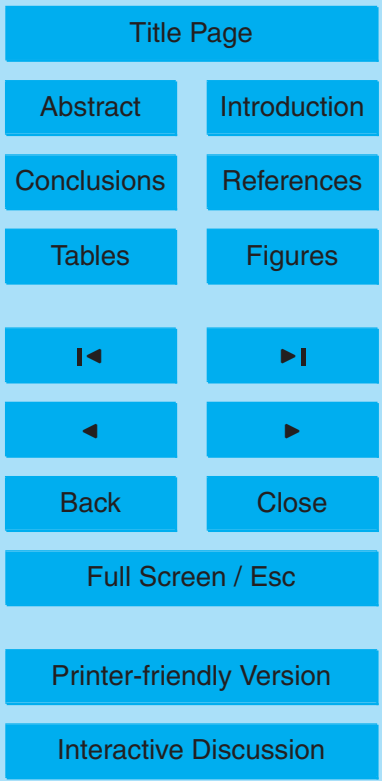




\section{Introduction}

Biomass burning has a major contribution to the emissions of tropospheric trace gases and aerosols particularly in the South Hemisphere. According to Giglio et al. (2006), in the period 2001-2004 the total area burned in Africa and Australia comprised 80\% of the area burned globally. Biomass burning in Australia occurs in two major regions: a) the tropical region in northern Australia with the savanna type vegetation of grass and shrubs with relatively low fuel loads but extensive area burned; and b) South-East Australia, the states of Victoria (VIC), New South Wales (NSW) and Australian Capital Territory (ACT), predominantly covered with eucalyptus forests with high fuel loads and relatively low area burned. South-East Australia has the reputation to be one of the three most fire-prone regions globally, along with southern California and southern France (Hennessy et al., 2005). The region has high population density with $70 \%$ (i.e. 14 million), of the 21 million population of Australia, living in these states. With an 15 estimate of emissions associated with wild forest fires being a factor of four higher than savanna burning (van der Werf et al., 2006), the air quality can be an issue during the biomass burning season, provided the air mass reaches the populated coastal regions. This study will cover the surface ozone $\left(\mathrm{O}_{3}\right)$ enhancement and aerosol loading during the devastating megafires in January 2003, which displaced 20500 people and burnt 260000 ha in VIC, NSW and ACT.

The 2002-2003 fire season in South-East Australia occurred during an on-going drought that was one of the most severe in recorded history with the first fires occurring early in the season in September 2002. The drought was associated with El Niño warm phase that caused prolonged rainfall deficiencies on the east coast of Australia for the six months to January 2003 with only half of the average rainfall recorded in the period July to December (Taylor and Webb, 2005; Leslie and Speer, 2006). In January 2003 the monthly mean temperature was about $2-3^{\circ} \mathrm{C}$ above average in northern $\mathrm{VIC}$ and

\section{3 megafires in} Australia

G. Guerova and N. Jones

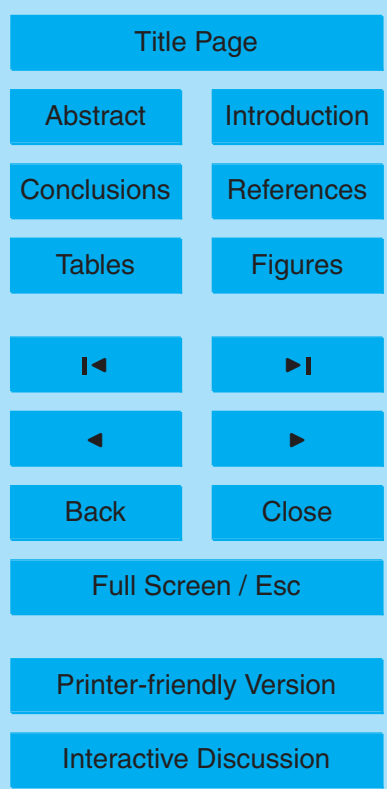


NSW (Taylor and Webb, 2005). In addition, the temperature from April to January was significantly above the average and, in November 2002, the maximum monthly mean temperature was $5^{\circ} \mathrm{C}$ above the average (Taylor and Webb, 2005). High temperature and low rainfall facilitated the curing of both fine and heavy fuel prior to January 2003, 5 providing an abundance of dry fuel primed for burning. Taylor and Webb (2005) discuss in great detail the synoptic and local conditions associated with the devastating fires in January 2003 and report that the wildfire activity initiated by lightning in VIC and NSW on 7-8 January was not completely brought under control until early March 2003. The interplay of hot air, low humidity in the evening and strong winds associated with 10 a strong frontal system moving through the South-East Australia facilitated the spread of fire (Taylor and Webb, 2005). Ultimately, high lightning activity and extreme fire weather days led to the ignition and rapid spread of a number of large, unplanned fires and economic damage estimate of around \$354 m. in loss of dwellings (over 500 in Canberra on 18 January), buildings and stock.

15 Surface ozone $\left(\mathrm{O}_{3}\right)$ and particulate matter are of most concern for air quality (Jacob and Winner, 2008). In clean surface air, the $\mathrm{O}_{3}$ mixing ratio is typically in the range 5-30 ppb (Jacob, 1999). The surface $\mathrm{O}_{3}$ is toxic to humans and vegetation because it oxidises biological tissue. $\mathrm{O}_{3}$ is produced in the troposphere from the oxidation of $\mathrm{CO}$ and hydrocarbons in the presence of $\mathrm{NO}_{\mathrm{x}}$. In densely populated regions with high emissions of $\mathrm{NO}_{x}$ and hydrocarbons, rapid $\mathrm{O}_{3}$ production can take place and result in surface air pollution problems. $\mathrm{O}_{3}$ is produced during biomass burning, which is the second largest $\mathrm{NO}_{x}$ and $\mathrm{CO}$ emission source globally. Surface $\mathrm{O}_{3}$ is subject to air quality regulation in Australia. The air quality threshold is $80 \mathrm{ppb}$, for 4-h rolling average, and $100 \mathrm{ppb}$ for 1 -h average. Elevated concentration of surface $\mathrm{O}_{3}$ affects the linings of the throat and lungs, restricting the air passages and makes breathing difficult. It also increases the risk of respiratory infections (EPA Victoria, http://www.epa.vic.gov. au/air/issues/air_03.asp). Atmospheric aerosols are of major concern for public health and climate change, but their sources and atmospheric distributions remain poorly constrained. Atmospheric aerosols have natural, as well as anthropogenic, sources.

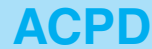

9, 3007-3040, 2009

2003 megafires in Australia

G. Guerova and N. Jones

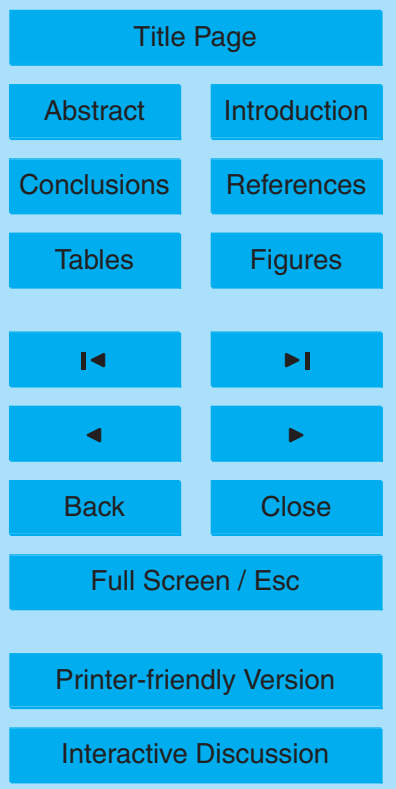

3010 
Natural sources include wind-blown dust, sea salt, large-scale dust storms, naturally occurring forest fires, and volcanic eruptions.

Fires are a major air quality concern in Australia. In 2003, all surface $\mathrm{O}_{3}$ standard exceedences in Victoria were due to fires (EPA, 2004b). Forest fire frequency in Australia

5 is projected to increase (Hennessy et al., 2005) in a warmer climate and to become the major source of particulate matter globally (Jacob and Winner, 2008). The Australian urban areas are particularly susceptible to photochemical smog because of local meteorological conditions, high solar radiation, and emission of local pollutants (Manins, 2001). Sydney is a classic closed basin, bounded by high-altitude land to the south, 10 west, and north, and pollution may accumulate and circulate inside the city for several days, exacerbated by relatively frequent temperature inversions (Gupta et al., 2007). Gupta et al. (2006) report that the air-quality conditions in Sydney during fire events are comparable to the conditions in highly polluted cities such as Hong Kong and New Delhi. Of particular concern are particulate matter that can enter into eyes and respiratory system and can cause health effects such as burning eyes and sore throat (EPA Victoria, http://www.epa.vic.gov.au/air/issues/air_part.asp). People with existing respiratory or heart conditions such as: congestive heart failure, angina, chronic obstructive pulmonary disease, emphysema, or asthma are more sensitive to the effects of smoke. Exposure to particulate matter can aggravate these conditions. Existing symptoms may get worse when exposed to smoke. Children and the elderly may also be more sensitive to the effects of smoke than healthy people.

In this study we use the state-of-art global chemistry and transport model GEOSChem in conjunction with ground- and space-based observations to study $\mathrm{O}_{3}$ and aerosol enhancement during the 2003 fires in South-East Australia. The paper is or25 ganised as follows: Sect. 2 presents the datasets used; the GEOS-Chem model setup is presented in Sect. 3; Sect. 4 gives a summary of the temporal and spatial variability of $\mathrm{O}_{3}$ and AOD in January 2003 and 2004; a detailed study of four episodes in January 2003 is available in Sect. 5; and conclusions are given in Sect. 6.

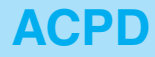

9, 3007-3040, 2009

\section{3 megafires in} Australia

G. Guerova and N. Jones

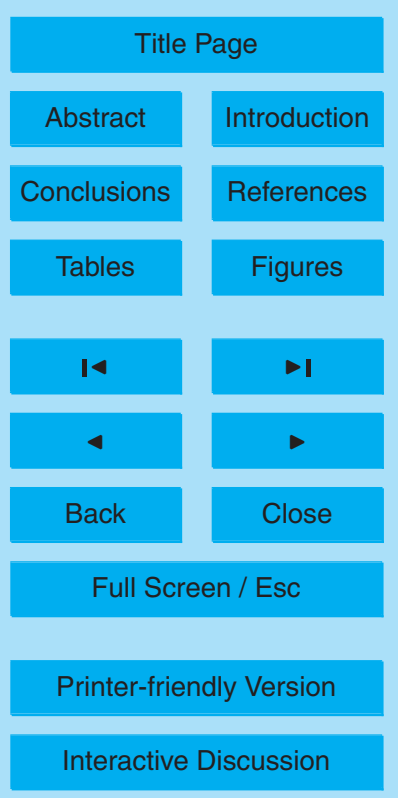




\section{Observation datasets}

\subsection{Aerosol optical depth from MODIS}

Terra and Aqua are polar orbiting satellites of the NASA Earth Observing System (Salomonson et al., 1989; King et al., 1992, 2003) which carry Moderate Resolu5 tion Imaging Spectroradiometer (MODIS) instruments that take global Aerosol Optical Depth (AOD) observations twice daily. MODIS spatial resolution is $250 \mathrm{~m}$ at nadir, has a $2330 \mathrm{~km}$ wide swath, and spectral range in 36 channels, 7 of which are dedicated for aerosol retrieval $(470,550,650,850,1240,1650$ and $2130 \mathrm{~nm})$. We use the Level-2 product with $10 \mathrm{~km}$ resolution available through the LAADS web 10 (http://ladsweb.nascom.NASA.gov/data/) that is averaged to GEOS-Chem resolution of $2^{\circ}$ latitude by $2.5^{\circ}$ longitude.

MODIS AOD products over the ocean are generally unbiased with low uncertainty (Remer, 2002; Levy et al., 2005), but the land AOD products are subject to higher uncertainty and a persistent high bias (Ichoku et al., 2002; Kinne, 2003; Chin et al., 2004; Matsui et al., 2004; Abdou et al., 2005; Levy et al., 2005).

\subsection{Surface observations EPA}

We use data from Environment Protection Authority (EPA) air quality monitoring networks of South Australia, Victoria and New South Wales. The NSW air quality monitoring program collects real-time measurements of ambient level pollutants at 24 monitoring stations located around the greater metropolitan area of Sydney, the Illawarra ( $80 \mathrm{~km}$ south), the Lower Hunter (90 km north) and selected rural sites around NSW (http://www.environment.nsw.gov.au/AQMS/sitesyd.htm). Of these, 15 residential and 3 rural stations report $\mathrm{O}_{3}$. The EPA Victoria operates $\mathrm{O}_{3}$ air quality monitoring in 11 residential and 4 rural stations (http://www.epa.vic.gov.au/air/bulletins/airmonlc.asp). In 2003, $\mathrm{O}_{3}$ exceeded the standards on 5 days, which is more frequent than in recent years. In January 2003, EPA Victoria reports $\mathrm{O}_{3}$ exceedences of the 1-h (100 ppb) and

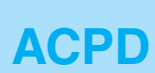

9, 3007-3040, 2009

2003 megafires in Australia

G. Guerova and N. Jones

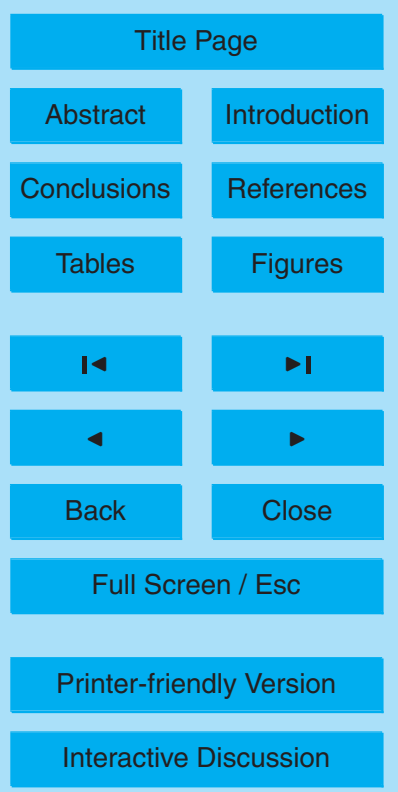


4-h (80 ppb) standards on the 17th, 24th and 25th (EPA, 2004b). Each of the exceedences occurred during the fires in Victoria and New South Wales. South Australia EPA operates an air quality network with four $\mathrm{O}_{3}$ monitoring sites in the metropolitan area of Adelaide (http://www.epa.sa.gov.au/index.html). No exceedences of the 4-h standard 5 are reported in South Australia in January 2003 (EPA, 2004a).

\section{Model description}

The three-dimensional global chemistry and transport model GEOS-Chem, version 704-11, with a horizontal resolution of 2degree latitude by 2.5 degree longitude and 30 vertical levels from the surface to $0.01 \mathrm{hPa}$ (http://www.as.harvard.edu/chemistry/trop/ geos/), is used in this work. The model is driven by the NASA Global Circulation Model GEOS-4 with a temporal resolution of 3 and $6 \mathrm{~h}$. Online chemistry with 43 tracers provides a comprehensive description of the $\mathrm{NO}_{\mathrm{x}}-\mathrm{O}_{\mathrm{x}}$-hydrocarbon chemistry and of tropospheric aerosols, which include nitrate-ammonium-sulfate aerosols, mineral dust, sea salt, black and organic carbon, and secondary organic aerosols. A total of 350 chemical reactions are taken into account in the chemical mechanism for 90 different species, as described in Park et al. (2004). The photolysis rates are calculated with the Fast-J algorithm which accounts for clouds and aerosols (Wild and Akimoto, 2001). Dry deposition velocities are computed following Wesely (1989) and Wang et al. (1998). Wet deposition is applied to gases, dust and hydrophilic aerosols as described in Liu et al. (2003).

Anthropogenic emissions of $\mathrm{NO}_{\mathrm{x}}, \mathrm{CO}, \mathrm{SO}_{2}$ are from EDGAR3.2, the hydrocarbons and sulfur are from the Global Emissions Inventory Activity (GEIA) for 1985 (Benkovitz et al., 1996) with updated national emissions inventories and are scaled for specific years (Bey et al., 2001; Park et al., 2004). Over Europe, North America and northern Mexico, anthropogenic $\mathrm{NO}_{\mathrm{x}}, \mathrm{CO}$, hydrocarbon and sulfur emissions are taken from the European Monitoring and Evaluation Program (EMEP) for the year 2000, (Auvray and Bey, 2005) the EPA National Emissions Inventory (NEI99) for the year 1998 and

2003 megafires in Australia

G. Guerova and N. Jones

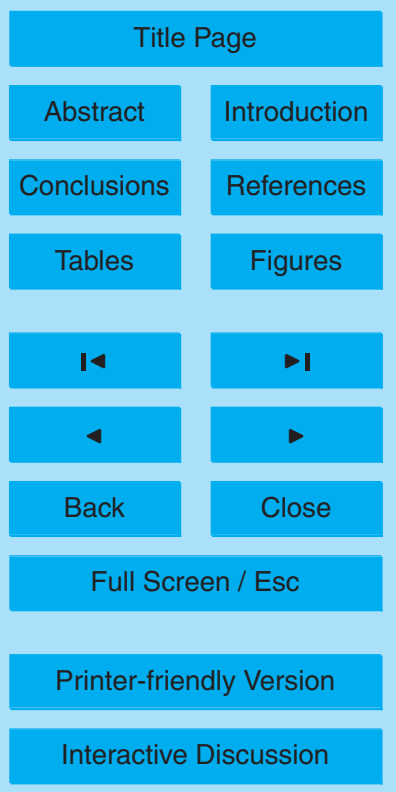

Interactive Discussion 
BRAVO. Anthropogenic emissions for $\mathrm{NO}_{\mathrm{x}}$ and $\mathrm{CO}$ over Asia are from Streets et al. (2003) and Streets et al. (2006). Biomass burning emissions are from the Global Fire Emissions Database (GFED2), (van der Werf et al., 2006) and biogenic emissions are calculated online using the MEGAN algorithm described by Guenther et al. (2006).

5 Included are also aircraft and lightening $\mathrm{NO}_{\mathrm{x}}$ and ship $\mathrm{SO}_{2}$ emissions. Soil $\mathrm{NO}_{\mathrm{x}}$ emissions are computed following Yienger and Levy (1995) with canopy reduction factors described by Wang et al. (1998).

Presented here are the results from a standard simulation that follows the set up described above for January 2003 and 2004 obtained after a one-year spin-up. Sensitivity 10 simulations were conducted with biomass burning emissions turned off successively. Subtraction of the results from the sensitivity simulation from those of the standard simulation allows us to quantify the fraction of $\mathrm{O}_{3}$ that is solely a result of a specific $\mathrm{O}_{3}$ precursor source. Due to non-linearity in the $\mathrm{O}_{3}$ tropospheric chemistry, one has to be cautious when interpreting the results of the sensitivity simulations.

For the intercomparison with EPA observations, the model data are sampled every two hours from which the afternoon daily and monthly means are computed. The EPA data is averaged over individual GEOS-Chem grid and all grids with observations are averaged and presented in Fig. 4.

\section{Australian fires: January 2003 versus January 2004}

\section{4.1 Surface ozone and aerosol enhancement}

Figure 1 presents the January 2003 fire hotspots detected by the ATSR sensor (http://dup.esrin.esa.int/ionia/wfa/index.asp) on board of the European Space Agency satellite. Clearly visible is the hotspot arc in Victoria and New South Wales. During 2002-2003 wild forest fires peaked in January 2003, which is about one month later 25 than other years.

The model simulations in January 2003 show a large surface $\mathrm{O}_{3}$ enhancement over

2003 megafires in Australia

G. Guerova and N. Jones

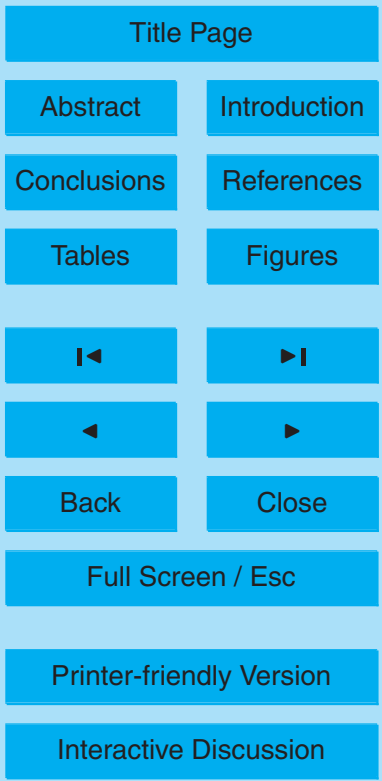

Interactive Discussion 
South-East Australia (Fig. 2a) with monthly mean of 50 ppb. In comparison, the monthly mean surface $\mathrm{O}_{3}$ in January 2004 (Fig. 2b) is about 30 ppb. Similarly, the simulated AOD is roughly doubled in January 2003 (Fig. 2c) when compared with January 2004 (Fig. 2d).

5 GEOS-Chem has been the subject of numerous global and regional evaluations that demonstrate the model skill in the reproduction of general features of tropospheric chemistry. The model has previously been the subject of several global evaluations (Bey et al., 2001; Martin et al., 2003; Park et al., 2004). However, this is first study focused on Australia, thus the model evaluation is presented in Table 1 using the surface $10 \mathrm{O}_{3}$ observations from NSW, VIC and SA. In January 2003, the simulated monthly mean surface $\mathrm{O}_{3}$ across the three states reaches $41 \mathrm{ppb}$, which is about $18 \mathrm{ppb}$ higher that in January 2004; while the observed $\mathrm{O}_{3}$ is $28 \mathrm{ppb}$, which is only $2 \mathrm{ppb}$ higher than in 2004. The large differences between model and observations are attributed to a factor of two overestimation in the simulated $\mathrm{O}_{3}$ in NSW. This overestimation will be further 5 addressed in Sect. 5. Note that in VIC and SA the simulated and observed $\mathrm{O}_{3}$ agree within $7 \mathrm{ppb}$ in 2003 and $3 \mathrm{ppb}$ in 2004, thus the impact of fires will be quantified in those two states only. The monthly mean afternoon $\mathrm{O}_{3}$ in January 2003 increased by $30 \%$ i.e. $8-13 \mathrm{ppb}$ (column 4 in Table 1). Thus, an averaged $\mathrm{O}_{3}$ mixing ratio of $10 \mathrm{ppb}$ will be used as threshold in Sect. 4.2.

20 Over South-East Australia, the simulated monthly mean AOD in 2003 is 0.084 which is a factor of three higher than in 2004 (Table 2). The observed MODIS AOD is 0.191 in January 2003, which is a factor of two higher than in 2004 (Table 2). Similarly the observed AOD at Cape Grim station is about a factor of two higher in 2003. Note, however, that the model underestimates the reported enhancement from both MODIS and Cape Grim station. This underestimation will be further discussed in Sect. 4.2.

The model sensitivity simulations are used to deduce the fire impact on surface $\mathrm{O}_{3}$ in January 2003 and 2004. In January 2003, between 20 to $50 \%$ of the surface $\mathrm{O}_{3}$ in South-East Australia can be attributed to the fires (Fig. 3a). In central Australia and New Zealand the fires contributed to a $10 \%$ increase in the surface $\mathrm{O}_{3}$. In contrast, in

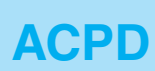

9, 3007-3040, 2009

2003 megafires in Australia

G. Guerova and N. Jones

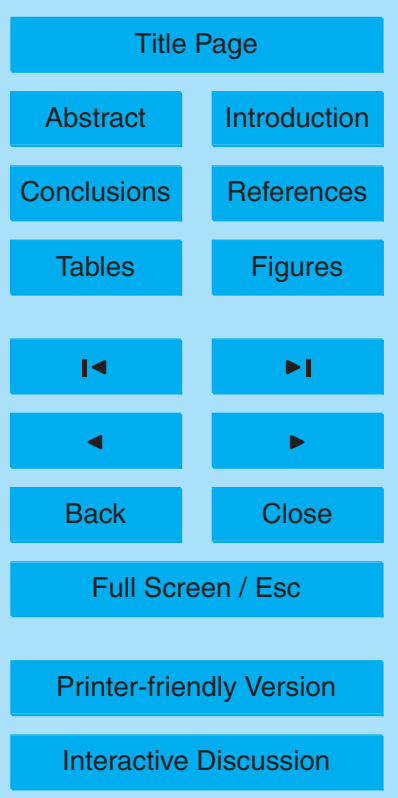




\subsection{Temporal variation of surface $\mathrm{O}_{3}$ and AOD}

In order to test the GEOS-Chem skill in reproducing the temporal variation of afternoon (12:00-18:00 AEDT) surface $\mathrm{O}_{3}$ in January, 2003, the EPA observations from Victoria 5 and South Australia are plotted against the simulated (Fig. 4). Several features stand out: i.) a very good correlation $(r=0.83)$ with a high statistical significance $(P<0.1 \%$ level) between observed and simulated $\mathrm{O}_{3}$; ii.) six distinct episodes when the observed daily averaged surface $\mathrm{O}_{3}$ reached $40 \mathrm{ppb}$, two in the first half of the month and four in the second half; and iii.) overestimation of the simulated $\mathrm{O}_{3}$ during three episodes, 10 namely 12, 17 and 24 January. In order to gain an insight into a possible reason for the model overestimation during these episodes we examined the observed $\mathrm{O}_{3}$ at 15 stations in VIC. On 12 January 2003, the observed $\mathrm{O}_{3}$ is in the range $16-66 \mathrm{ppb}$. Ten out of 13 stations reported $\mathrm{O}_{3}$ above $40 \mathrm{ppb}$ and 3 stations below $40 \mathrm{ppb}$. Similarly, on 17 January 2003, the observed $\mathrm{O}_{3}$ range is $21-89 \mathrm{ppb}$ and 9 out of 15 stations reported above $40 \mathrm{ppb}$. At one station, $\mathrm{O}_{3}$ exceeded the 4-h air quality threshold of $80 \mathrm{ppb}$. On 24 January 2003, 10 out of 15 stations reported $\mathrm{O}_{3}$ above $40 \mathrm{ppb}$ and the range is $17-80 \mathrm{ppb}$.

As seen in Fig. 4 the simulated $\mathrm{O}_{3}$ range (gray vertical bar) is in good agreement with the observed range (black vertical bar). During the episodes on 17 and 29 January, the 20 simulated range closely traces the observed. During the 12 and 24 January episodes, the simulated $\mathrm{O}_{3}$ range is at the higher end of the observed.

Model sensitivity simulations are used to identify the major fire episodes. An episode is classified as major provided the $\mathrm{O}_{3}$ mixing ratio, due to solely fire (dashed gray line in Fig. 4), is above $10 \mathrm{ppb}$, a threshold inferred in Sect. 4.1. Four episodes satisfy this 25 criteria, one during the first half of the month (12 January) and three in the second half $(17,24$ and 29 January 2003). The episode on January 29 is well simulated, thus the contribution from the fires can be inferred to be $15 \mathrm{ppb}$. Note, however, that on this day the observed $\mathrm{O}_{3}$ mixing ratio is in the range 38-74 ppb with 14 out of 15
9, 3007-3040, 2009

2003 megafires in Australia

G. Guerova and N. Jones

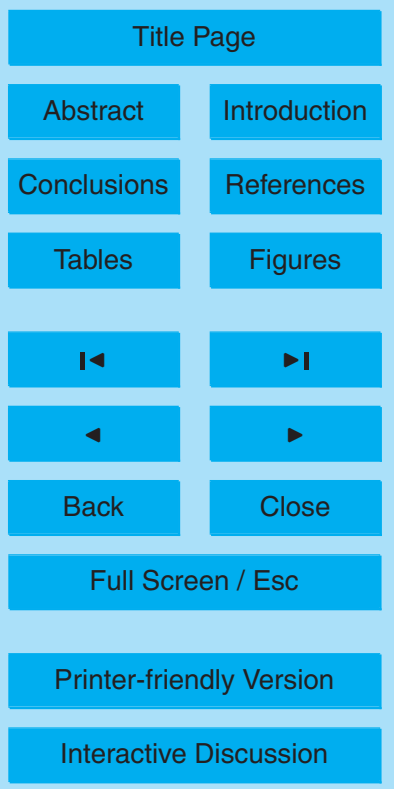

Interactive Discussion 
stations in Victoria above $40 \mathrm{ppb}$. If we assume that the station reporting the lowest concentration is representative for a clean air environment and the station reporting the maximum ozone enhancement represents the polluted air environment, then the difference gives an $\mathrm{O}_{3}$ enhancement of $36 \mathrm{ppb}$. This is roughly double the one obtained 5 from model sensitivity simulation. Application of this method to the remaining three events will help to quantify the impact of fire. For the episode on 24 January, the observed versus simulated $\mathrm{O}_{3}$ enhancement is $63 \mathrm{ppb}$ versus $50 \mathrm{ppb}$. For the second episode on 17 January, the difference in the observed and simulated $\mathrm{O}_{3}$ enhancement is $68 \mathrm{ppb}$ and $25 \mathrm{ppb}$, respectively. For the first episode on 12 January, the observed $10 \mathrm{O}_{3}$ enhancement is $50 \mathrm{ppb}$ compared with $40 \mathrm{ppb}$ simulated. The correlation between the observed $\mathrm{O}_{3}$ range and the simulated $\mathrm{O}_{3}$ enhancement due to fire is 0.67 and is highly statistically significant $(P<0.1 \%)$.

In the day-to-day variability in the AOD, three out of four episodes associated with the fires in South-East Australia are clearly seen in both GEOS-Chem and MODIS 15 (Fig. 5). From these episodes, on 24 January, the AOD enhancement measured by MODIS peaks at 1.0, which is a factor of 5 higher than the monthly mean AOD (0.19). Note that GEOS-Chem tends to underestimate the observed peak AOD on both 24 and 29 January. In addition, the model tends to underestimate the AOD in both January, 2003 and 2004, and exhibits a partial skill in reproducing the temporal variation $(r=0.4$ 20 in 2003 and $r=0.5$ in 2004) with low statistical significance $(P<5 \%)$. As the MODIS observations have known positive bias over land, a comparison with Cape Grim data from a sun photometer is used to quantify a possible bias over SA and VIC. The AOD observed at Cape Grim (black stars in Fig. 5) is in good agreement with the satellite data, in particular, during the second half of January, 2003. The monthly mean AOD from MODIS and sun photometer at Cape Grim is 0.17 and 0.15 respectively while GEOS-Chem AOD is 0.06 , i.e. a factor of two to three. It is to be noted that both sun photometer and MODIS observations reflect cloud-free day-time conditions, thus they differ from GEOS-Chem. However, due to the large difference between simulated and observed $A O D$, further discussion will be limited to qualitative only.

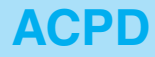

9, 3007-3040, 2009

2003 megafires in Australia

G. Guerova and N. Jones

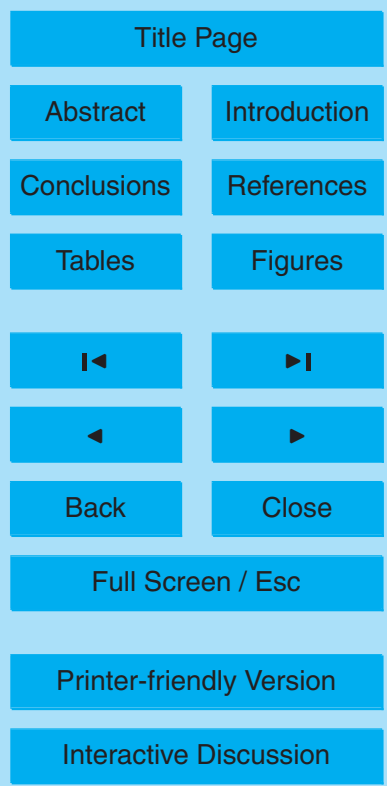




\section{3 megafires: case studies}

The four major fire episodes (ES) identified in Sect. 4.2 are summarised in Table 3 and discussed in detail below.

\subsection{Episode I: 12 January 2003}

5 The weather regime on 12 January is characterised by an anticyclone in the Tasman Sea. It can be seen in Fig. $6 \mathrm{~b}$ that over South-East Australia the wind turns from east (E) to north-east (NE). As expected, the fire air mass reaches the metropolitan areas of Melbourne in Victoria, Adelaide in South Australia and the Southern Ocean (Fig. 6a). The observed maximum surface $\mathrm{O}_{3}$ enhancement in Victoria reaches $66 \mathrm{ppb}$ 10 while the simulated is $70 \mathrm{ppb}$. It is to be noted that in Victoria both the model and the observation show a well pronounced west-east $\mathrm{O}_{3}$ gradient, i.e. $40-50 \mathrm{ppb}$ to the west and $10-20 \mathrm{ppb}$ to the east. This is an indication of regional differences and suggests that the large variability in the observed $\mathrm{O}_{3}$ is driven by two distinct air masses: one from the fires and one from the clean Tasman Sea environment.

15 A patch of enhanced AOD is observed west of Tasmania (Fig. 6d) which is in agreement with the simulated AOD and can be traced back to the mainland Australia (Fig. 6c).

\subsection{Episode II: 17 January 2003}

A detailed summary of the atmospheric circulation on 17 January is given in Taylor and Webb (2005). Passage of a broad frontal system deteriorated the fire conditions in NSW and fires in ACT spread rapidly under the influence of strong winds. On 18 January, the Forest Fire Danger Index (FFDI), an index used in Australia to assess the likelihood and severity of fires, reached 104. The "extreme" fire danger index threshold is 50 or above. In Fig. 7a, strong winds in the range of $10 \mathrm{~m} / \mathrm{s}(36 \mathrm{~km} / \mathrm{h})$ are seen close

2003 megafires in Australia

G. Guerova and N. Jones

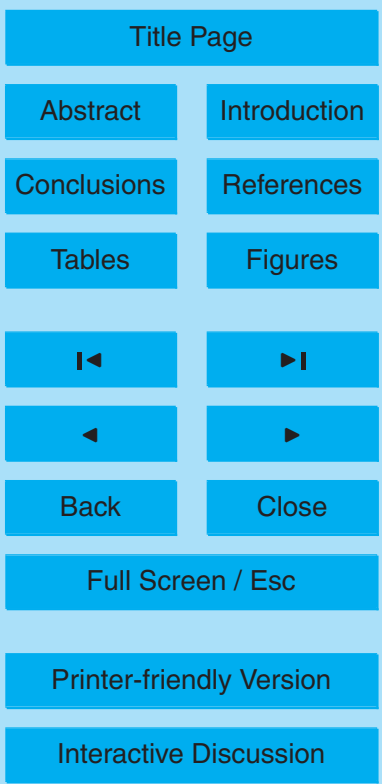

Interactive Discussion 
locate. The afternoon surface $\mathrm{O}_{3}$ mixing on 17 January in ACT, NSW and VIC is in the range $40-80 \mathrm{ppb}$. One EPA station in VIC reports an average $\mathrm{O}_{3}$ of $89 \mathrm{ppb}$ and 9 out of 15 stations report values in the $40-80 \mathrm{ppb}$ range. Note, the observed $\mathrm{O}_{3}$ gradient in the metropolitan Sydney area $\left(34^{\circ} \mathrm{S}, 151^{\circ} \mathrm{N}\right)$. While the coastal stations report $\mathrm{O}_{3}$

5 mixing ratio of $20 \mathrm{ppb}$ on average, the inland stations report $40-80 \mathrm{ppb}$ (Fig. 7a). This gradient is further discussed in the next section.

In Fig. 7d, the observed AOD peaks along the coastal area of the Tasman Sea. $A O D$ represents the aerosol load in the entire troposphere thus reflecting the faster transport in the free troposphere, and the slow down of winds close to the surface.

10 The simulated AOD (Fig. 7c) is in agreement with the satellite observation, but the model tends to underestimate the aerosol load over the Tasman Sea, which reflects among other things, the coupling to the hydrological cycle, particularly water vapour and clouds. Note that the simulated AOD is low all over the region with exception of central Australia.

$15 \quad 5.3$ Episode III: 24-25 January 2003

On 25 January, a well-formed anti-cyclone over Tasman Sea is seen in Fig. 8b. Over South-East Australia, the prevailing wind is from the north $(\mathrm{N})$ and the wind speed is in the range $5-10 \mathrm{~m} / \mathrm{s}$. Note in addition, a strong northerly flow east of Tasmania with wind speeds reaching $16 \mathrm{~m} / \mathrm{s}$. In Fig. $8 \mathrm{a}$, the surface $\mathrm{O}_{3}$ enhancement reflects the 20 wind flow and the simulated $\mathrm{O}_{3}$ reaches $60 \mathrm{ppb}$ over the Tasman Sea. The observed $\mathrm{O}_{3}$ in Victoria is in good agreement with the simulated which is in the range 32-56 ppb. Once again the EPA observations in New South Wales show similar patterns to that reported in Sect. 5.2, which probably reflects photochemical $\mathrm{O}_{3}$ formation from anthropogenic sources. As discussed earlier, the metropolitan Sydney area is a closed 25 basin, bounded by an escarpment with average altitudes of $500 \mathrm{~m}$ to the south, west and north. During fair weather summer afternoons, sea breeze conditions develop with light wind coming from the relatively cool water to the warm land. Those conditions
favour the inland development of photochemical smog and can possibly explain the favour the inland development of photochemical smog and can possibly explain the

2003 megafires in Australia

G. Guerova and N. Jones

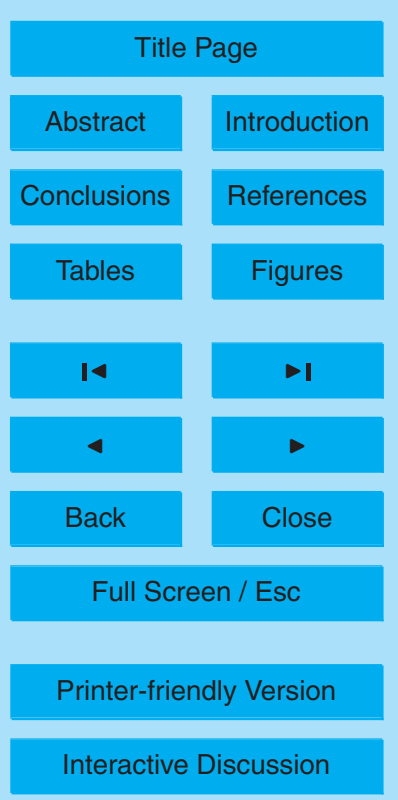


west-east gradient. In addition, the topography serves as a barrier for atmospheric flow. Note, however, that sea breeze circulation is difficult to resolve in a global model.

A close investigation of MODIS AODs show aerosol enhancement above 0.5 over Tasmania, the Tasman Sea and the South Island of New Zealand (Fig. 8d). The sim5 ulated AOD confirms the enhancement over Tasmania and the Tasman Sea but does not reach New Zealand (Fig. 8c). Despite its patchy nature, the observed high AODs hint at possible mid-tropospheric long range transport of fire smoke to New Zealand. This is further investigated below.

According to Taylor and Webb (2005), on 26 January 2003 the atmospheric circula10 tion is driven by a cold front with a pre-frontal trough moving east through South-East Australia. Clearly seen in Fig. 9b is a strong north-west (NW) wind channel across the Tasman Sea. Ahead of the wind channel is an anti-cyclone and behind it, at the point where the winds change to westerlies (W) east of Tasmania, is the cold front. The NW wind channel is a very efficient pathway for pollution transport between Australia and

15 New Zealand with estimated transport time between $24-36 \mathrm{~h}$. Similar wind channelling is reported in spring 2003 (Edwards et al., 2006) as well as over the North Atlantic (Guerova et al., 2006). Also clearly seen in Fig. $9 a$ is $\mathrm{O}_{3}$ in the range $40-60 \mathrm{ppb}$ across the Tasman Sea and the west coast of New Zealand. The simulated AOD also suggests an increase over the Tasman Sea and the South Island of New Zealand. Note, 20 however, that there appears to be a time lag between the simulated and observed $A O D$, i.e. the observed AOD peak is to the north of the simulated. Due to the patchiness of MODIS data, it is difficult to draw a definite conclusion, but it is highly likely that the smoke affected air mass reached the North Island of New Zealand on 26 January 2003. On 26 January the fire reached the Sydney metropolitan area (Fig. 9a) and after the frontal passage, the $\mathrm{O}_{3}$ dropped below $20 \mathrm{ppb}$ in Victoria.

\subsection{Episode IV: 29 January 2003}

In a very similar weather situation to the one reported in Sect. 5.3, with a blocking anti-cyclone over the Tasman Sea (Fig. 10b) and cold front approaching Victoria on 29

2003 megafires in Australia

G. Guerova and N. Jones

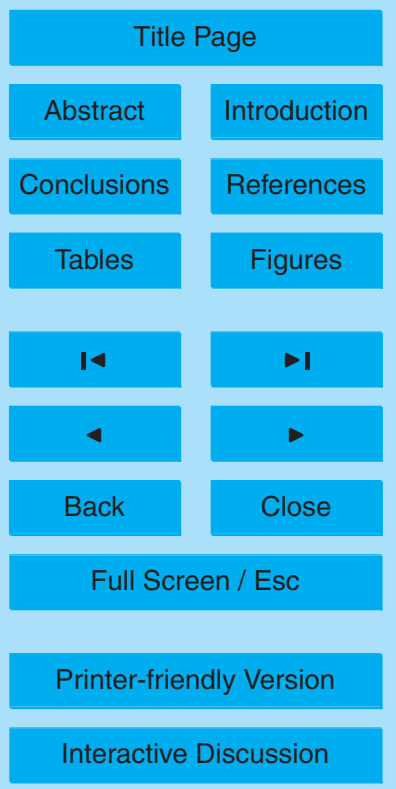


January, the fire smoke reached the metropolitan area of Melbourne and the average surface $\mathrm{O}_{3}$ increased to $50 \mathrm{ppb}$ from $20 \mathrm{ppb}$ on 27 January (Fig. 4). At 14 out of 15 stations, the observed afternoon $\mathrm{O}_{3}$ is in the range $40-80 \mathrm{ppb}$. The simulated surface $\mathrm{O}_{3}$ peaks to the east of the metropolitan area of Melbourne (Fig. 10a). The observed 5 and simulated AOD peaks over the Bass Strait, between mainland Australia and Tasmania, and South-East coast of Australia (Fig. 10c and d). Note, in addition, that close to the west coast of New Zealand, the AOD reaches 0.5 . On 30 January, similar northwest (NW) wind channelling occurred across the Tasman Sea (not shown) but the wind speed was roughly doubled, i.e. $30 \mathrm{~m} / \mathrm{s}$ and long range transport of $\mathrm{O}_{3}$ and aerosols 10 took place. The observed surface $\mathrm{O}_{3}$ in Melbourne dropped rapidly to $15 \mathrm{ppb}$ after the frontal passage on 30 January.

\section{$5.5 \mathrm{O}_{3}$ enhancement due to fires}

The described change in the weather regime, Sects. 5.3 and 5.4 , driven by the passage of the cold front, is an opportunity to quantify the contribution of the fires to the surface $\mathrm{O}_{3}$ concentration over South-East Australia. As seen in Fig. 4, in both episodes the observed surface $\mathrm{O}_{3}$ peaks at $50 \mathrm{ppb}$ before the frontal passage on 25 and 29 January and drops to 20 and $15 \mathrm{ppb}$ after the frontal passage on 27 and 30 January, respectively. Thus, an increase of 35 and $30 \mathrm{ppb}$ can be attributed to the fire. The model attributes 50 and $15 \mathrm{ppb} \mathrm{O}_{3}$ increases due to fires during the two episodes. For the other two episodes on 12 and 17 January, the observed surface $\mathrm{O}_{3}$ peaks at 40 and $45 \mathrm{ppb}$ respectively, before dropping to $20 \mathrm{ppb}$. This gives 20 and $25 \mathrm{ppb}$ enhancement due to fires. The average simulated enhancement is 40 and $25 \mathrm{ppb}$, respectively. Based on the 4 episodes the range of observed $\mathrm{O}_{3}$ enhancement over South-East Australia is $20-35 \mathrm{ppb}$ which is a factor of 3 to 5 higher than the monthly mean of $6.5 \mathrm{ppb}$

(Table 1). The simulated $\mathrm{O}_{3}$ enhancement is in the range $15-50 \mathrm{ppb}$ with a factor of 1.5 to 5 higher than the monthly mean of $10 \mathrm{ppb}$. The estimated here $\mathrm{O}_{3}$ enhancement due to fires represents $20-65 \%$ of the $80 \mathrm{ppb}$ air quality threshold. Despite the coarse model resolution and possible transport error associated with the timeliness of

2003 megafires in Australia

G. Guerova and N. Jones

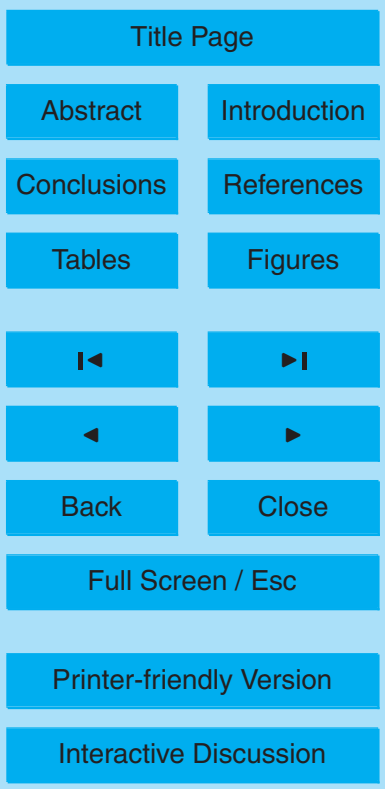

Interactive Discussion 
the frontal passage, GEOS-Chem is a backbone of this study and is a valuable tool in analysing the fire driven air quality. The ongoing development of multiple model nesting will allow extension of this analysis to the NSW region, which was excluded from this work due to consistent model overestimation possibly driven by the topography and 5 local effects.

\section{Summary and conclusions}

The exceptionally severe 2002-2003 fire season in South-East Australia is closely linked to the prolonged El Niño driven drought. The fires in South-East Australia started in early January, 2003 and the surface $\mathrm{O}_{3}$ and aerosol loading roughly doubled when 10 compared to January, 2004. On 17, 24 and 25 January $2003 \mathrm{O}_{3}$ exceedences were reported in Victoria, all due to the fires in Victoria and New South Wales. From model sensitivity simulations, four episodes are identified on 12, 17, 24-25 and 29 January 2003, during which the fires contribute more than $10 \mathrm{ppb}$ to the surface $\mathrm{O}_{3}$. These episodes are studied in detail in order to quantify the $\mathrm{O}_{3}$ and AOD enhancement and 15 typical weather regimes.

During three episodes, an anti-cyclone is located east of mainland Australia over the Tasman Sea. On 26 and 30 January, a distinct surface north-west wind channel is formed across the Tasman Sea between the anti-cyclone and the cold front behind it, through which the pollution crossed the Tasman Sea and reached New Zealand. 20 This type of long range pollution transport has been reported over the North Atlantic and its main characteristic is that it takes place on a short time span, i.e. 24-36 h. The passage of the cold front resulted in a drop in surface $\mathrm{O}_{3}$ and AOD over SouthEast Australia. This change from polluted to clean environments allows us to quantify the $\mathrm{O}_{3}$ contribution due to fires. Based on the 4 episodes, the range of observed $\mathrm{O}_{3}$ enhancement due to fires is $20-35 \mathrm{ppb}$, which is a factor of 3 to 5 higher than the monthly mean $\mathrm{O}_{3}$ of $6.5 \mathrm{ppb}$. The simulated fire $\mathrm{O}_{3}$ enhancement is in the range 15$50 \mathrm{ppb}$ with a factor of 1.5 to 5 higher than the monthly mean of $10 \mathrm{ppb}$. Note that the

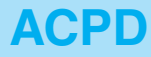

9, 3007-3040, 2009

2003 megafires in Australia

G. Guerova and N. Jones

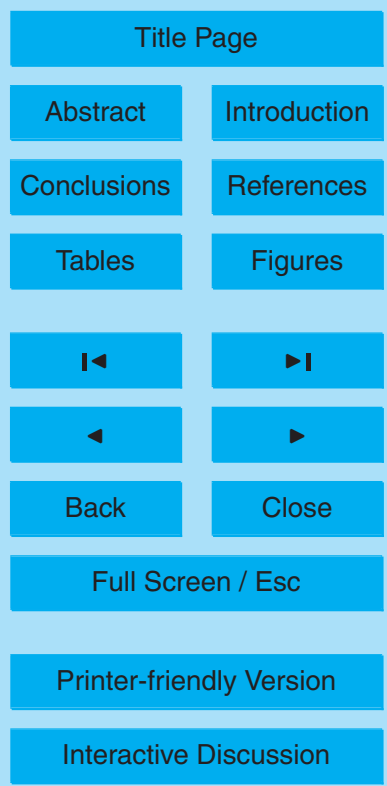


model exhibits very good skills in representing the temporal variation of the observed $\mathrm{O}_{3}$ with the correlation of 0.83 but shows a tendency to overestimate the peak $\mathrm{O}_{3}$ which is possibly linked to the relatively coarse resolution.

A factor of two increase in the aerosol load occurred during January, 2003 fires.

5 The model shows a tendency to underestimate the AOD, but proves a useful tool for reconstruction of the mostly patchy observed MODIS AODs. Over South-East Australia and the Tasman Sea, the simulated and observed AODs agree well for the spatial structure. On 24 January 2003, the observed AOD enhancement peaks at 1.00, which is a factor of five higher than the monthly mean AOD. As the AODs represent the 10 particulate matter load in the troposphere, it also reflects the faster transport in the free troposphere and the AOD enhancements are seen roughly a day ahead of the surface $\mathrm{O}_{3}$ enhancement.

GEOS-Chem is a backbone of this study and is a valuable tool in analysing the fire driven air quality in South-East Australia. The model resolution is a limiting fac15 tor for application of this study to the Sydney basin. The ongoing development of multiple GEOS-Chem nesting will allow extension of this analysis to the NSW region. In addition, a possible coupling of the GEOS-Chem Near-Real-Time (NRT) simulations (http://coco.atmos.washington.edu/cgi-bin/ion-p?page=geos_nrt.ion) with Sentinel (http://sentinel.ga.gov.au/acres/sentinel/), the national fire monitoring system, will 20 provide a useful tool for chemical weather forecasting and nowcasting of the air quality due to fires in Australia.

Acknowledgements. This study is funded by ARC Discovery Project "Biomass Burning Emissions - An Innovative Technique for Assessing Global Climate Impacts". The GEOS-Chem is managed by the Atmospheric Chemistry Modeling Group at Harvard University with support 25 from the NASA Atmospheric Chemistry Modelling and Analysis Program. We are grateful to the Australian Partnership for Advanced Computing (APAC) for resources and support. We would like to acknowledge the MODIS, NSW, VIC and SA EPA teams for providing observation data. The data from Cape Grim station was kindly provided by S. Wilson from University of Wollongong.

2003 megafires in Australia

G. Guerova and N. Jones

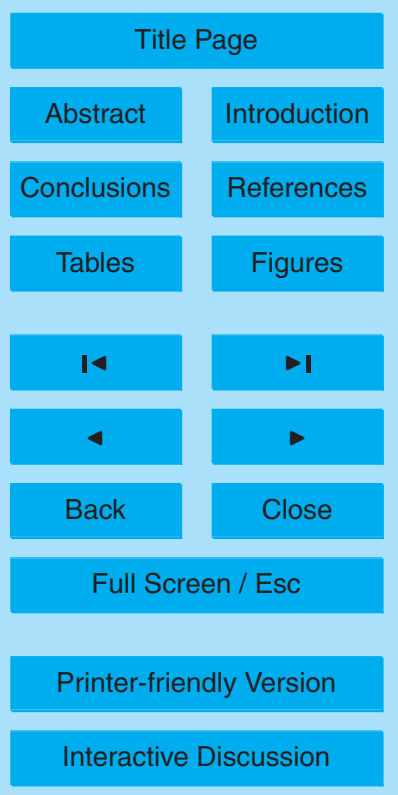

Interactive Discussion 


\section{References}

Abdou, W. A., Diner, D., Martonchik, J., Bruegge, C., Kahn, R., Gaitley, B., Crean, K., Remer, L., and Holben, B.: Comparison of coincident Multiangle Imaging Spectroradiometer and Moderate Resolution Imaging Spectroradiometer aerosol optical depths over land and ocean scenes containing Aerosol Robotic Network sites, J. Geophys. Res., 110, D10S07, doi:10.1029/2004JD004693, 2005. 3012

Auvray, M. and Bey, I.: Long-range transport to Europe: seasonal variations and implications for the European ozone budget, J. Geophys. Res., 110, D11303, doi:10.1029/2004JD005503, 2005. 3013

Benkovitz, C. M., Scholtz, M. T., Pacyna, J., Tarrasin, L., Dignon, J., Voldner, E. C., Spiro, P. A., Logan, J. A., and Graedel, T. E.: Global gridded inventories of anthropogenic emissions of sulfur and nitrogen, J. Geophys. Res., 101, D22, doi:10.1029/96JD00126, 1996. 3013

Bey, I., Jacob, D. J., Logan, J. A., and Yantosca, R. M.: Global modeling of tropospheric chemistry with assimilated meteorology: model description and evaluation, J. Geophys. Res., 106, 23073-23095, 2001. 3013, 3015

Chin, M., Chu, A., Levy, R., Remer, L., Kaufman, Y., Holben, B., Eck, T., Ginoux, P., and Gao, Q.: Aerosol distribution in the Northern Hemisphere during ACE-Asia: results from global model, satellite observations, and Sun photometer measurements, J. Geophys. Res., 109, D23S90, doi:10.1029/2004JD004829, 2004. 3012

20 Edwards, D. P., Emmons, L. K., Gille, J. C., Chu, A., Attie, J.-L., Giglio, L., Wood, S. W., Haywood, J., Deeter, M. N., Massie, S. T., Ziskin, D. C., and Drummond, J. R.: Satelliteobserved pollution from Southern Hemisphere biomass burning, J. Geophys. Res., 111, D14312, doi:10.1029/2005JD006655, 2006. 3020

EPA S. A.: Ambient Air Quality Monitoring, South Australia, 1979-2003, Tech. rep., EPA South Australia, Adelaide, http://www.epa.sa.gov.au/pub_air.html, 2004a. 3013

EPA V.: Air Monitoring Report 2003 - Compliance with the National Environment Protection (Ambient Air Quality) Measure, Tech. rep., EPA Victoria, Melbourne, http://www.epa.vic.gov. au/air/monitoring/air_monitoring_report_2003.asp, 2004b. 3011, 3013

Giglio, L., van der Werf, G. R., Randerson, J. T., Collatz, G. J., and Kasibhatla, P.: Global estimation of burned area using MODIS active fire observations, Atmos. Chem. Phys., 6, 957-974, 2006,

http://www.atmos-chem-phys.net/6/957/2006/. 3009
2003 megafires in Australia

G. Guerova and N. Jones

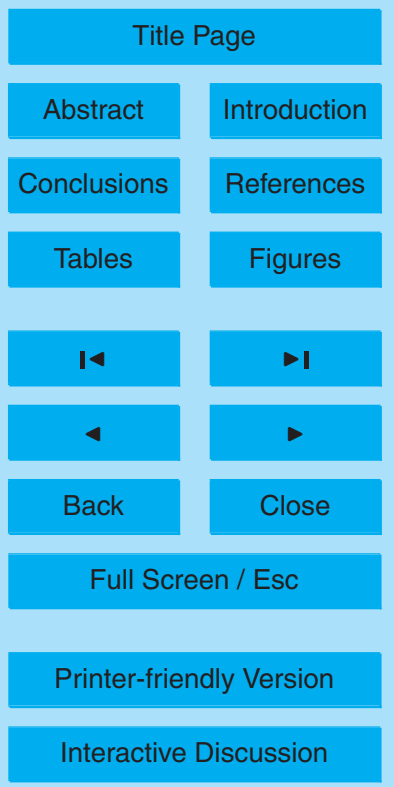


Guenther, A., Karl, T., Harley, P., Wiedinmyer, C., Palmer, P. I., and Geron, C.: Estimates of global terrestrial isoprene emissions using MEGAN (Model of Emissions of Gases and Aerosols from Nature), Atmos. Chem. Phys., 6, 3181-3210, 2006, http://www.atmos-chem-phys.net/6/3181/2006/. 3014

5 Guerova, G., Bey, I., Attié, J.-L., Martin, R. V., Cui, J., and Sprenger, M.: Impact of transatlantic transport episodes on summertime ozone in Europe, Atmos. Chem. Phys., 6, 2057-2072, 2006,

http://www.atmos-chem-phys.net/6/2057/2006/. 3020

Gupta, P., Christopher, S. A., Wang, J., Gehrigc, R., Leed, Y., and Kumare, N.: Satellite remote sensing of particulate matter and air quality assessment over global cities, Atmos. Environ., 40, 5880-5892, doi:10.1016/j.atmosenv.2006.03.016, 2006. 3011

Gupta, P., Christopher, S. A., Box, M., and Box, G.: Multi year satellite remote sensing of particulate matter air quality over Sydney, Australia, Int. J. Remote Sensing, 28(20), 16, doi:10.1080/01431160701241738, 2007. 3011

Hennessy, K., Lucas, C., Nicholls, N., Bathols, J., Suppiah, R., and Ricketts, J.: Climate change impacts on fire-weather in south-east Australia, Tech. rep., CSIRO Marine and Atmospheric Research Aspendale Victoria, 2005. 3009, 3011

Ichoku, C., Chu, D., Mattoo, S., Kaufman, Y., Remer, L., Tanre, D., Slutsker, I., and Holben, B.: A spatio-temporal approach for global validation and analysis of MODIS aerosol products,

20 Geophys. Res. Lett., 29(12), 8006, doi:10.1029/2001GL013206, 2002. 3012

Jacob, D. J.: Introduction to Atmospheric Chemistry, Princeton University Press, http://www.as. harvard.edu/people/faculty/djj/book/index.html, 1999. 3010

Jacob, D. J. and Winner, D. A.: Effect of climate change on air quality, Atmos. Environ., 43, 51-63, 2008. 3010, 3011

King, M. D., Kaufman, Y. J., Menzel, W. P., and Tanreacute, D.: Remote sensing of cloud, aerosol, and water vapor properties from the Moderate Resolution Imaging Spectrometer (MODIS), IEEE T. Geosci. Remote, 30, 2-27, 1992. 3012

King, M. D., Menzel, W. P., Kaufman, Y. J., Tanre, D., Gao, B.-C., Platnick, S., Ackerman, S. A., Remer, L. A., Pincus, R., and Hubanks, P. A.: Cloud and aerosol and water vapor properties, precipitable water, and profiles of temperature and humidity from MODIS, IEEE T. Geosci. Remote, 41, 442-458, 2003. 3012

Kinne, S.: Monthly averages of aerosol properties: A global comparison among models, satellite data, and AERONET ground data, J. Geophys. Res., 108, 4634,

2003 megafires in Australia

G. Guerova and N. Jones

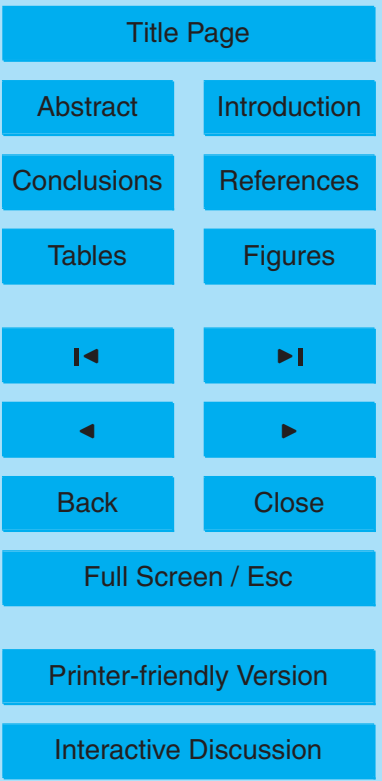


doi:10.1029/2001JD001253, 2003. 3012

Leslie, L. M. and Speer, M. S.: Modelling dust transport over central eastern Australia, Meteorol. Appl., 13, 141-167, doi:10.1017/S1350482706002155, 2006. 3009

Levy, C. R., Remer, L., Martins, J., Kaufman, Y., Plana-Fattori, A., Redemann, J., and Wenny,

$5 \quad$ B.: Evaluation of MODIS Aerosol Retrievals over Ocean and Land during CLAMS, J. Atmos. Sci., 62, 974-992, 2005. 3012

Liu, H., Jacob, D. J., Bey, I., Yantosca, R. M., Duncan, B. N., and Sachse, G. W.: Transport pathways for Asian pollution outflow over the Pacific: Interannual and seasonal variations, J. Geophys. Res., 108(D20), 8786, 2003. 3013

10 Manins, P.: Australia State of the Environment Report 2001, Tech. rep., Environmental Consulting and Research Unit, CSIRO Atmospheric Research, Aspendale Victoria, iSBN 0643 06746 9, 2001. 3011

Martin, R. V., Jacob, D., Yantosca, R., Chin, M., and Ginoux, P.: Global and Regional Decreases in Tropospheric Oxidants from Photochemical Effects of Aerosols, J. Geophys. Res., 108, D3, doi:10.1029/2002JD002622, 2003. 3015

Matsui, T., Kreidenweis, S., Sr., R. P., Schichtel, B., Yu, H., Chin, M., Chu, D., and Niyogi, D.: Regional comparison and assimilation of GOCART and MODIS aerosol optical depth across the eastern U.S., Geophys. Res. Lett., 31, L21101, doi:10.1029/2004GL021017, 2004. 3012

Park, R., Jacob, D. J., Field, B. D., Yantosca, R. M., and Chin, M.: Natural and transboundary pollution influences on sulfate-nitrate-ammonium aerosols in the United States: implications for policy, J. Geophys. Res., 109, D15204, doi:10.1029/2003JD004473, 2004. 3013, 3015

Remer, L. A.: Validation of MODIS aerosol retrieval over ocean, Geophys. Res. Lett., 29(12), 8008, doi:10.1029/2001GL013204, 2002. 3012

Salomonson, V. V., Barnes, W. L., Maymon, P. W., Montgomery, H. E., and Ostrow, H.: MODIS: Advanced facility instrument for studies of the earth as a system, IEEE T. Geosci. Remote, 27, 145-153, 1989. 3012

Streets, D. G., Bond, T., Carmichael, G., Fernandes, S., Fu, Q., Klimont, Z., Nelson, S., Tsai, N., Wang, M., Woo, J.-H., and Yarber, K. F.: An inventory of gaseous and primary aerosol emissions in Asia in the year 2000, J. Geophys. Res, 108(D21), 8809, doi:10.1029/2002JD003093, 2003. 3014

Streets, D. G., Zhang, Q., Wang, L., He, K., Hao, J., Wu, Y., Tang, Y., and Carmichael, G.: Revisiting China's CO emissions after the Transport and Chemical Evolution over the Pacific (TRACE-P) mission: Synthesis of inventories, atmospheric modeling, and observations, J.

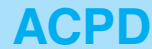

9, 3007-3040, 2009

2003 megafires in Australia

G. Guerova and N. Jones

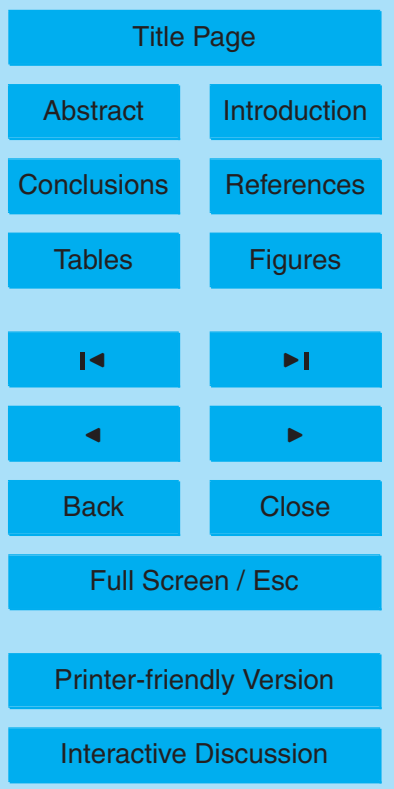


Geophys. Res, 111, D14306, doi:10.1029/2006JD007118, 2006. 3014

Taylor, J. and Webb, R.: Meteorological aspects of the January 2003 south-eastern Australia bushfire outbreak, Australian Forestry, 68, 94-103, 2005. 3009, 3010, 3018, 3020

van der Werf, G. R., Randerson, J. T., Giglio, L., Collatz, G. J., Kasibhatla, P. S., and Arellano $5 \quad J$ r., A. F.: Interannual variability in global biomass burning emissions from 1997 to 2004, Atmos. Chem. Phys., 6, 3423-3441, 2006, http://www.atmos-chem-phys.net/6/3423/2006/. 3009, 3014

Wang, Y., Jacob, D., and Logan, J.: Global simulation of tropospheric ozone-NO $\mathrm{N}_{\mathrm{x}}-\mathrm{Hydrocarbon}$ chemistry, J. Geophys. Res., 103, 10713-10768, 1998. 3013, 3014

10 Wesely, M.: Parameterization of surfaceresistance to gaseous dry deposition in regional-scale numerical models, Atmos. Environ., 23, 1293-1304, 1989. 3013

Wild, O. and Akimoto, $\mathrm{H} .:$ Intercontinental transport of ozone and its precursors in a three-dimensional global CTM, J. Geophys. Res., 106(D21), 27729-27744, doi:10.1029/2000JD000123, 2001. 3013

Yienger, J. J. and Levy, $\mathrm{H}$. : Empirical model of global soil-biogenic $\mathrm{NO}_{\mathrm{x}}$ emissions, J. Geophys. Res., 100, 11447-11464, 1995. 3014

\section{ACPD}

9, 3007-3040, 2009

\section{3 megafires in} Australia

G. Guerova and N. Jones

Title Page

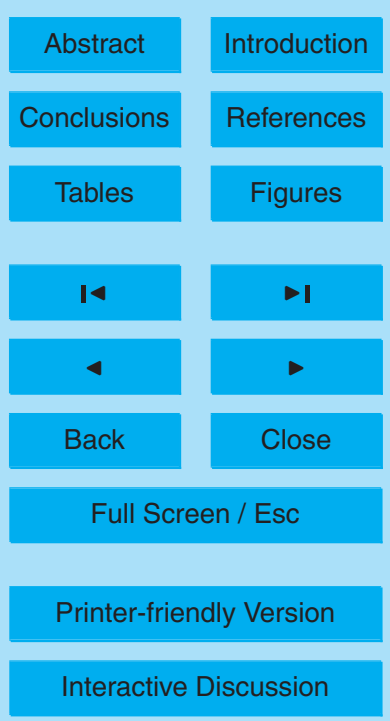




\section{ACPD}

\section{9, 3007-3040, 2009}

\section{3 megafires in}

Australia

Table 1. Monthly mean afternoon (12:00-18:00 AEDT) surface $\mathrm{O}_{3}$ in January 2003 (column 2) and 2004 (column 3). The difference between 2003 and 2004 is given in column 4 and 5.

\begin{tabular}{lcccc}
\hline & $\begin{array}{c}\mathrm{O}_{3}[\mathrm{ppb}] \\
\text { January 2003 }\end{array}$ & $\begin{array}{c}\mathrm{O}_{3}[\mathrm{ppb}] \\
\text { January 2004 }\end{array}$ & $\begin{array}{c}\mathrm{O}_{3} \\
\text { change [ppb] }\end{array}$ & $\begin{array}{c}\mathrm{O}_{3} \\
\text { change [\%] }\end{array}$ \\
\hline GEOS-Chem all & 41 & 23 & 18 & 78 \\
EPA all & 28 & 26 & 2 & 8 \\
GEOS-Chem NSW & 65 & 30 & 35 & 117 \\
EPA NSW & 33 & 37 & -4 & -11 \\
GEOS-Chem VIC & 32 & 19 & 13 & 68 \\
EPA VIC & 25 & 20 & 5 & 25 \\
GEOS-Chem SA & 27 & 19 & 8 & 42 \\
EPA SA & 30 & 22 & 8 & 36 \\
\hline
\end{tabular}

Title Page

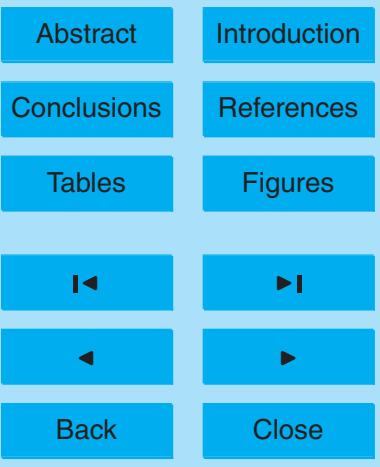

Full Screen / Esc

Printer-friendly Version

Interactive Discussion 


\section{ACPD}

\section{9, 3007-3040, 2009}

\section{3 megafires in}

Australia

G. Guerova and N. Jones

Table 2. Monthly mean AOD in January 2003 (column 2) and 2004 (column 3). The difference between 2003 and 2004 is given in column 4 and 5 .

\begin{tabular}{lcccc}
\hline & $\begin{array}{c}\text { AOD } \\
\text { January 2003 }\end{array}$ & $\begin{array}{c}\text { AOD } \\
\text { January 2004 }\end{array}$ & AOD change & AOD change [\%] \\
\hline GEOS-Chem VIC+SA & 0.084 & 0.028 & 0.056 & 200 \\
MODIS VIC+SA & 0.191 & 0.084 & 0.107 & 127 \\
Cape Grim & 0.150 & 0.086 & 0.064 & 74 \\
\hline
\end{tabular}

Title Page

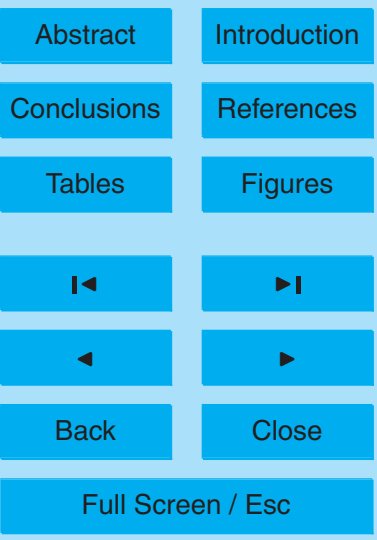

Printer-friendly Version

Interactive Discussion 


\section{ACPD}

9, 3007-3040, 2009

\section{3 megafires in Australia}

Table 3. Summary of fire episodes in January 2003. Column 1: Episode number. Column 2: Date. Column 3: Brief summary of the weather regime over South-East Australia. Column 4: Maximum wind speed and direction at surface. Column 5: MODIS AOD signature of the episode.

\begin{tabular}{lcccc}
\hline Episode & Date & $\begin{array}{c}\text { Weather } \\
\text { summary }\end{array}$ & $\begin{array}{c}\text { Wind speed } \\
\text { and direction }\end{array}$ & MODIS \\
\hline ES I & 12 & anti-cyclone & $5 \mathrm{~m} / \mathrm{s}$ & partly \\
& January & NE of Tasmania & E & \\
ES II & 17 & anti-cyclone & $0-5 \mathrm{~m} / \mathrm{s}$ & yes \\
& January & Tasman sea & $\mathrm{N}-\mathrm{NW}$ & \\
ES IIIA & $24-25$ & NW wind channel & $5-10 \mathrm{~m} / \mathrm{s}$ & yes \\
& January & across Tasman sea & $\mathrm{N}$ & \\
ES IIIB & 26 & NW wind channel & $5-15 \mathrm{~m} / \mathrm{s}$ & yes \\
& January & across Tasman sea & $\mathrm{NW}$ & \\
ES IV & 29 & anti-cyclone & $5-10 \mathrm{~m} / \mathrm{s}$ & yes \\
& January & Tasman sea & $\mathrm{N}$ & \\
\hline
\end{tabular}

Title Page

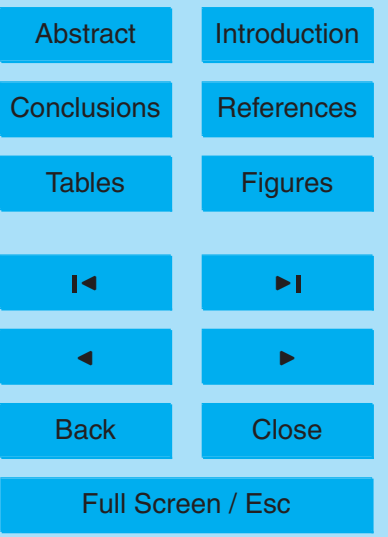

Printer-friendly Version

Interactive Discussion 


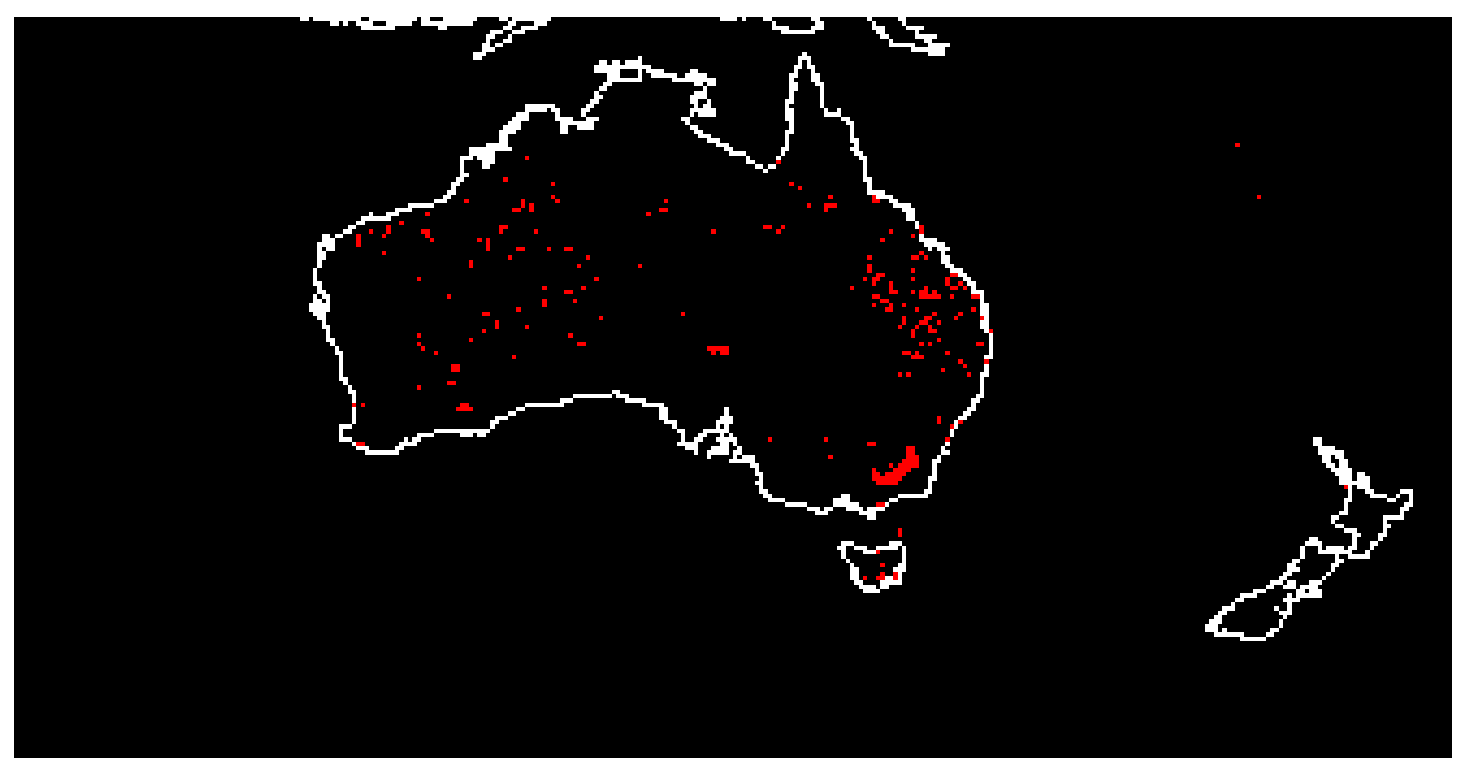

Fig. 1. ATSR fire hotspots over Australia in January 2003 (available from http://dup.esrin.esa. int/ionia/wfa/index.asp).

\section{ACPD}

9, 3007-3040, 2009

2003 megafires in Australia

G. Guerova and N. Jones

Title Page

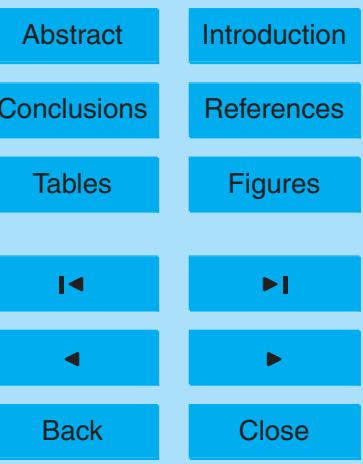

Full Screen / Esc

Printer-friendly Version

Interactive Discussion

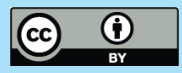


a.)

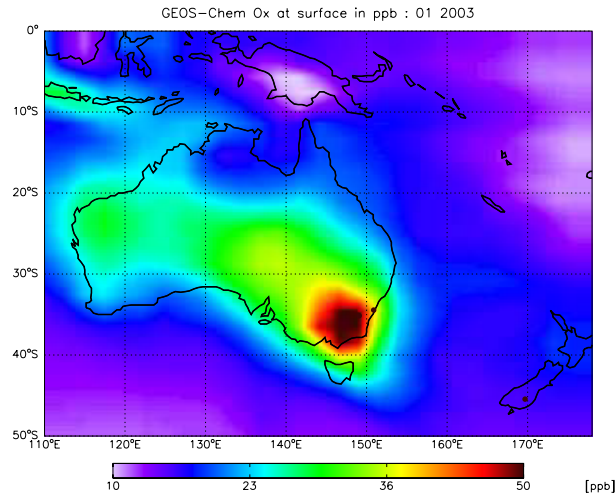

C.)

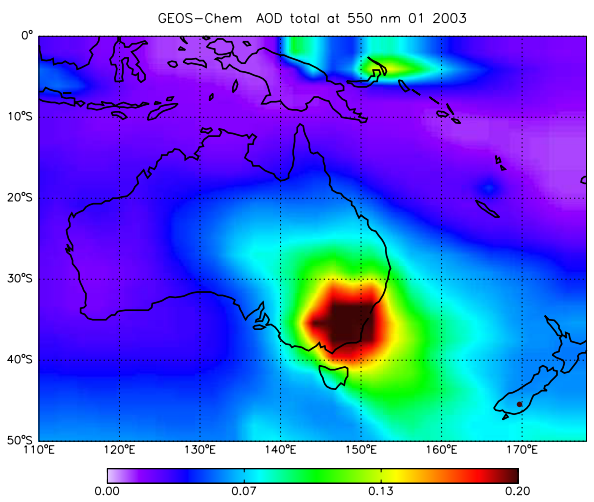

b.)

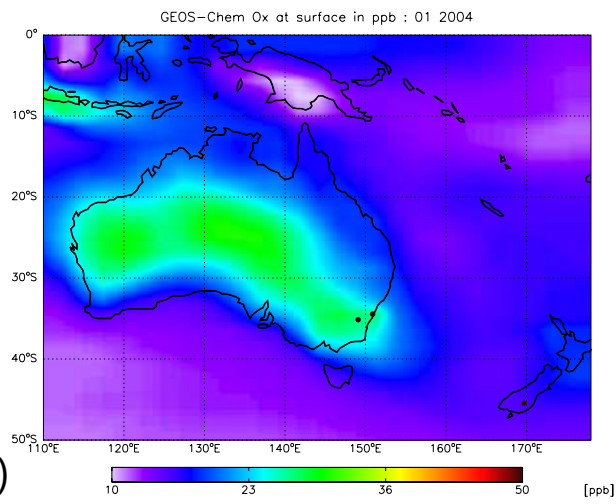

d.)

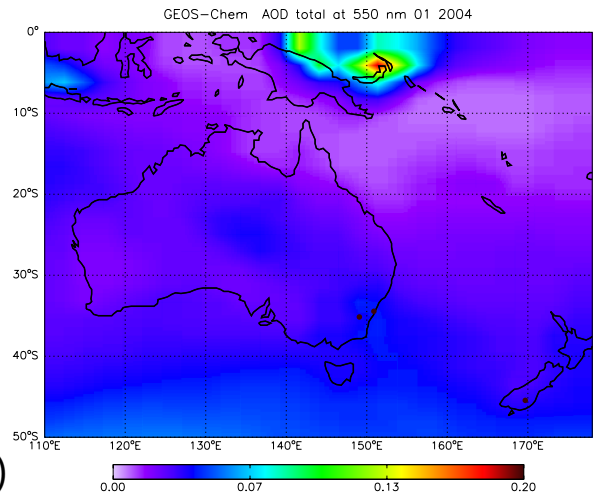

\section{ACPD}

9, 3007-3040, 2009

2003 megafires in Australia

G. Guerova and N. Jones

Title Page

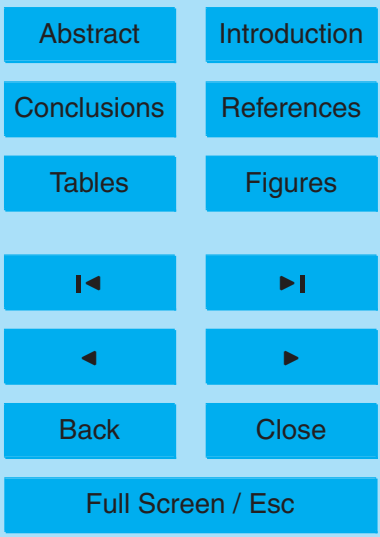

Printer-friendly Version

Interactive Discussion

Fig. 2. GEOS-Chem surface $\mathrm{O}_{3}$ [ppb]: (a) monthly mean January 2003, and (b) monthly mean January 2004. GEOS-Chem AOD at $500 \mathrm{~nm}$ : (c) monthly mean January 2003 and (d) monthly mean January 2004. 


\section{ACPD}

9, 3007-3040, 2009

\section{3 megafires in Australia}
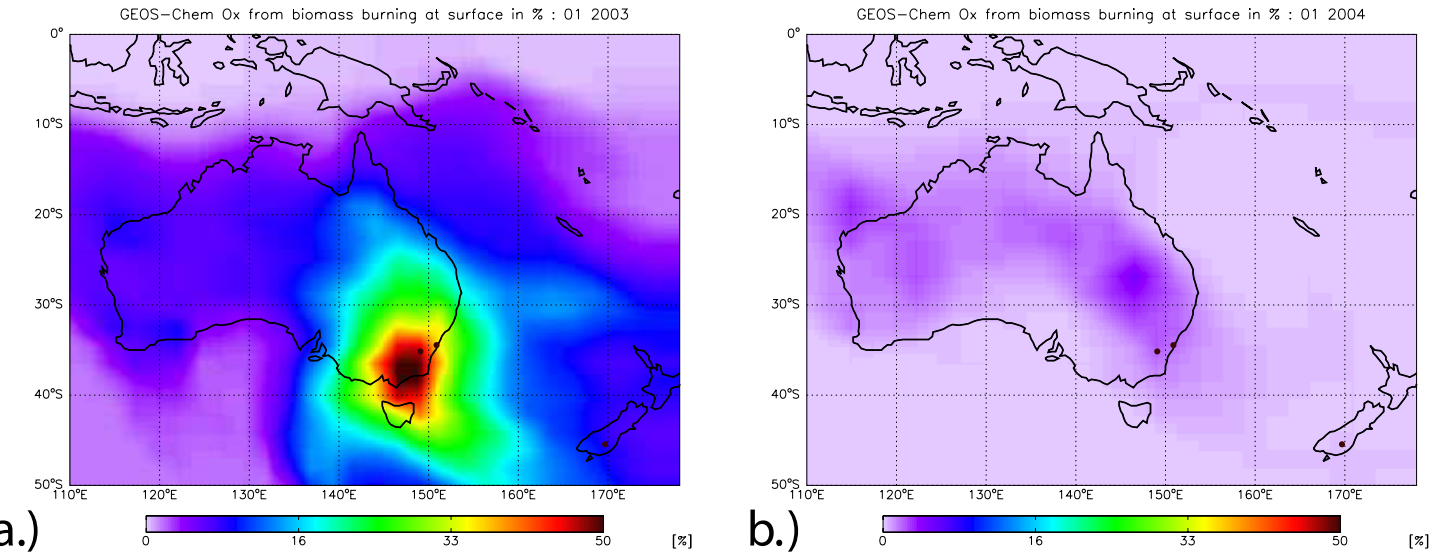

G. Guerova and N. Jones
Fig. 3. GEOS-Chem biomass burning sensitivity simulation. Surface $\mathrm{O}_{3}(\%)$ in January 2003 (a) and 2004 (b).
Title Page

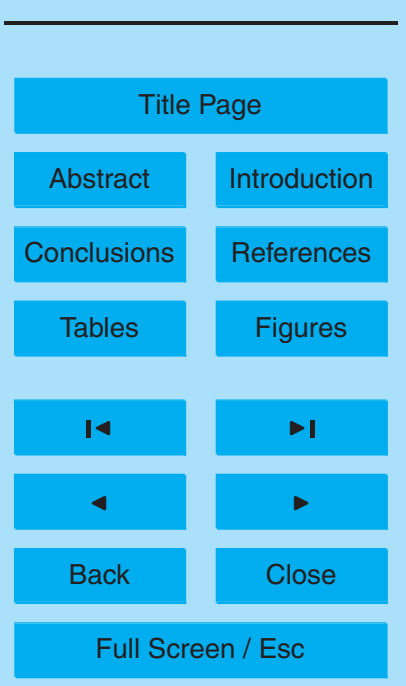

Printer-friendly Version

Interactive Discussion

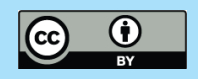




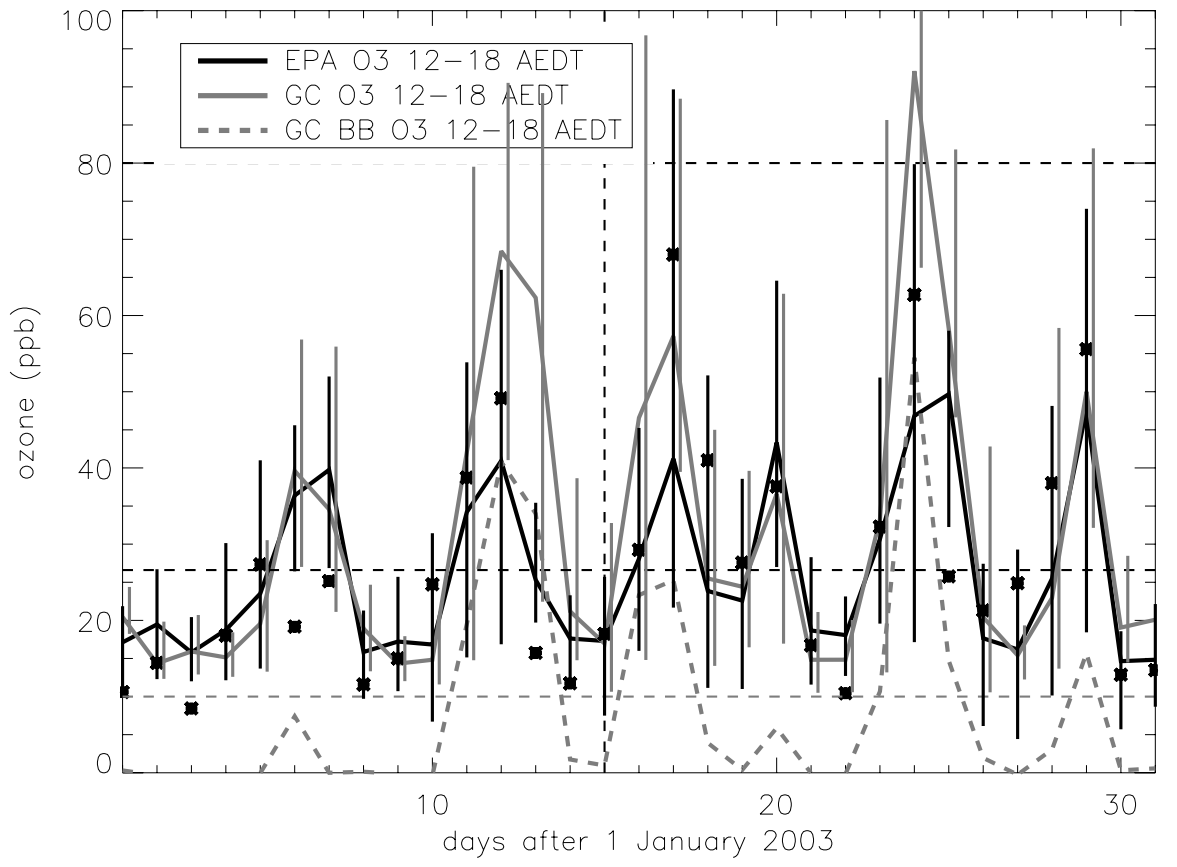

Fig. 4. Temporal variability of surface $\mathrm{O}_{3}$ over $\mathrm{SA}$ and VIC from GEOS-Chem (solid grey line) and EPA (solid black line). Note, that the EPA data is averaged from all stations in VIC and SA. Dashed gray line presents the biomass burning $\mathrm{O}_{3}$ contribution obtained from GEOS-Chem sensitivity simulation. The vertical bars show the observed and simulated $\mathrm{O}_{3}$ range while the black stars present the observed range. Note the good agreement between the observed $\mathrm{O}_{3}$ range (black stars) and the simulated $\mathrm{O}_{3}$ from biomass burning.
ACPD

9, 3007-3040, 2009

2003 megafires in Australia

G. Guerova and N. Jones

Title Page

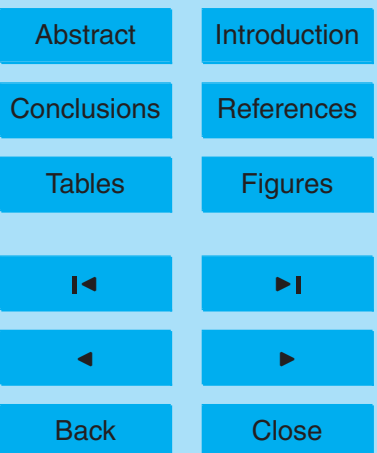

Full Screen / Esc

Printer-friendly Version

Interactive Discussion 


\section{ACPD}

\section{9, 3007-3040, 2009}

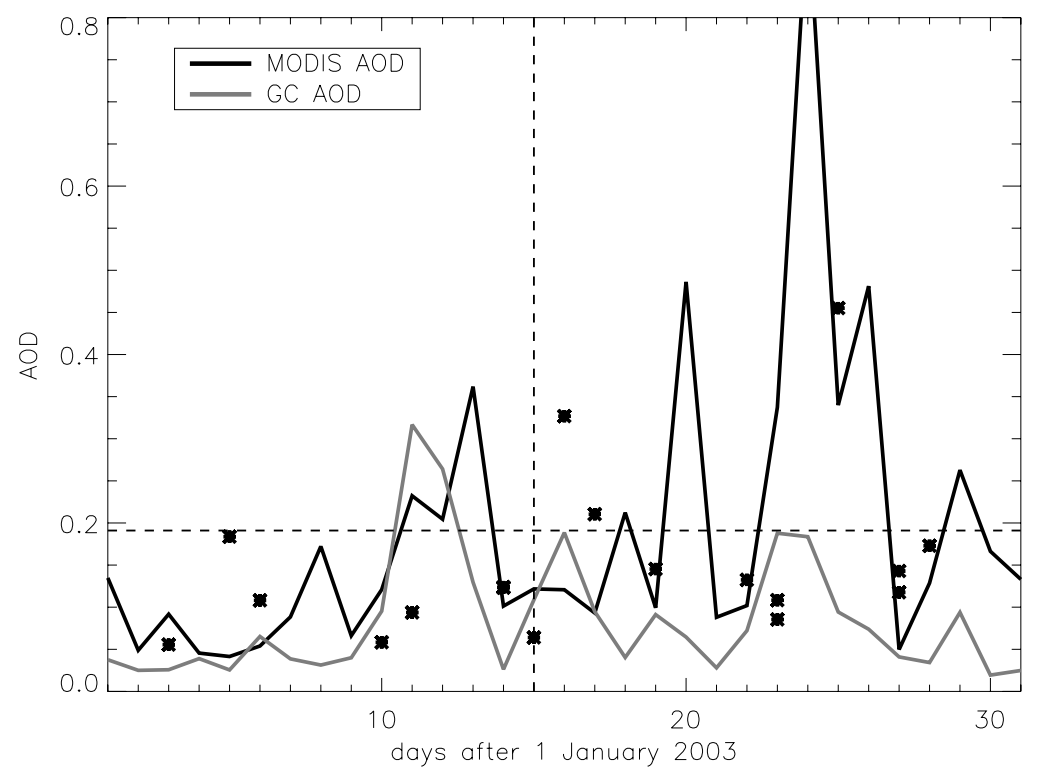

\section{3 megafires in}

Australia

G. Guerova and N. Jones

Title Page

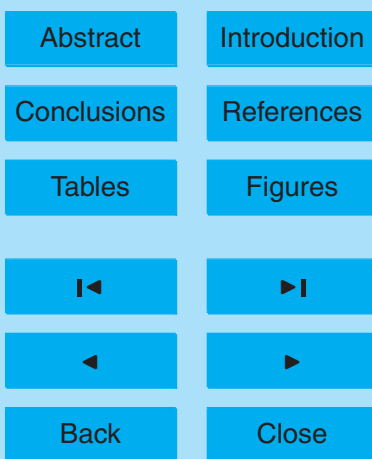

Fig. 5. Temporal variability of AOD over South Australia and Victoria from GEOS-Chem (solid grey line) and MODIS (solid black line). The AOD from Cape Grim station are presented with black dots. The horizontal dashed line indicates the observed monthly mean AOD of 0.191. The vertical dashed line separates the first and the second half of the month.

Full Screen / Esc

Printer-friendly Version

Interactive Discussion

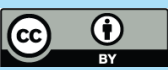




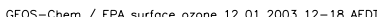

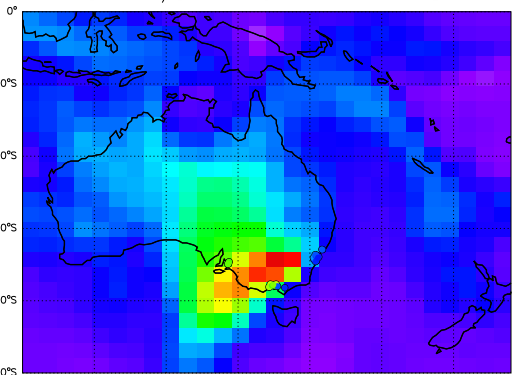

a.)

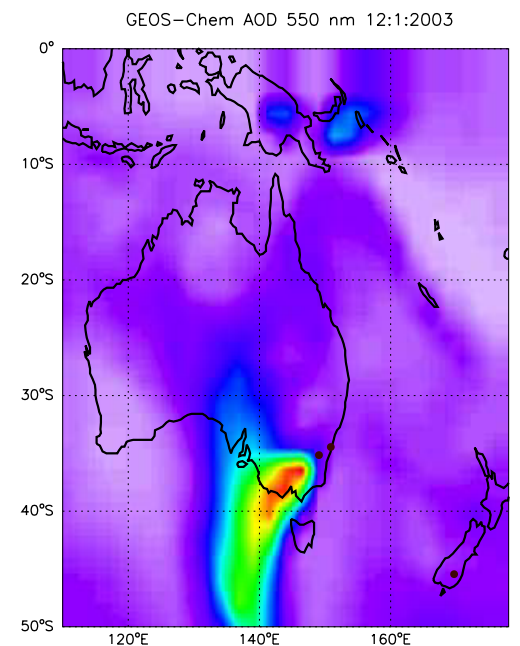

c.)

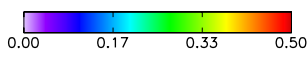

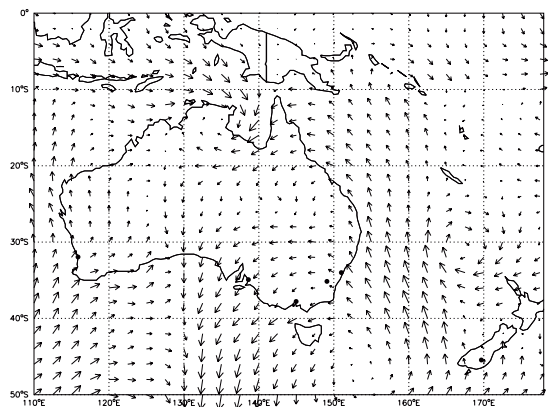

b.)

MODIS AQUA\&TERRA AOD 12:1:2003

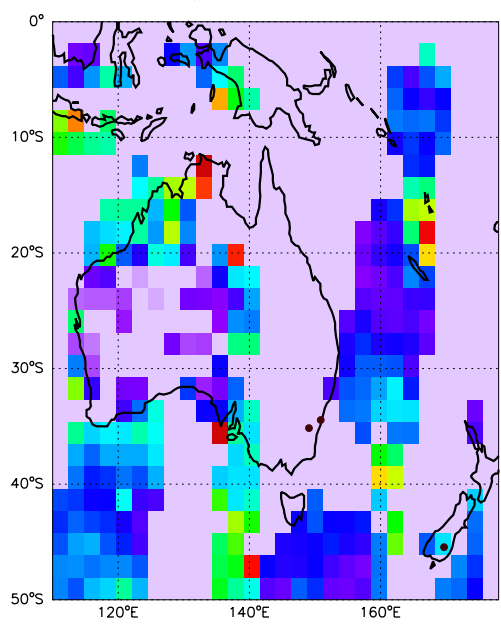

\begin{tabular}{lllll}
\hline & & & \\
& 0.00 & 0.17 & 0.33 & 0.50
\end{tabular}
ACPD

9, 3007-3040, 2009

2003 megafires in Australia

G. Guerova and N. Jones

Title Page

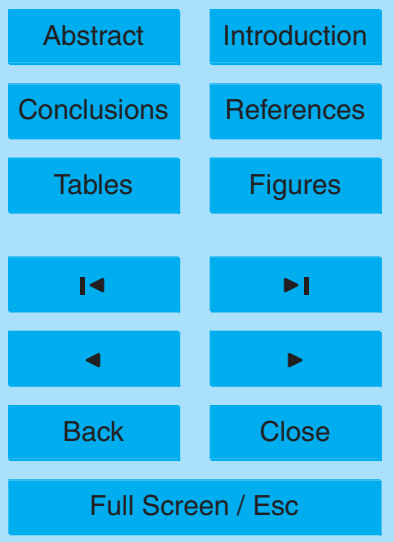

Printer-friendly Version

Interactive Discussion

Fig. 6. Episode I: (a) GEOS-Chem surface $\mathrm{O}_{3}$ (colour map) with EPA observations (coloured dots) on 12 January 2003. (b) GEOS-Chem surface wind. (c) and (d) GEOS-Chem and MODIS AODs: 12 January 2003. 


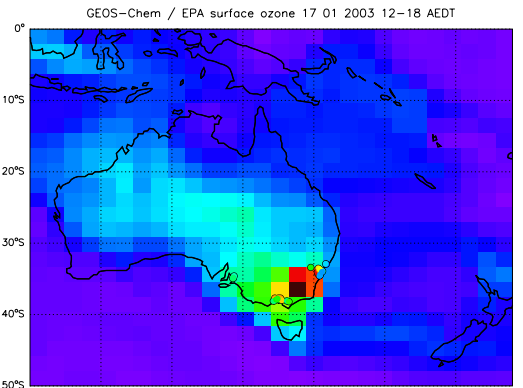

a.)

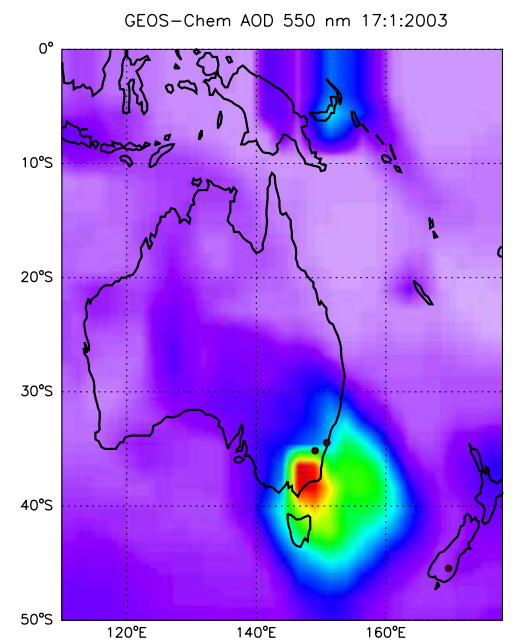

c.)

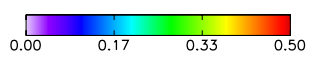

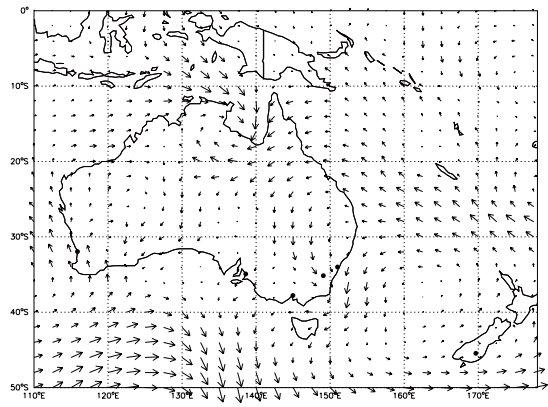

b.)

MODIS AQUA\&TERRA AOD $\quad 17: 1: 2003$

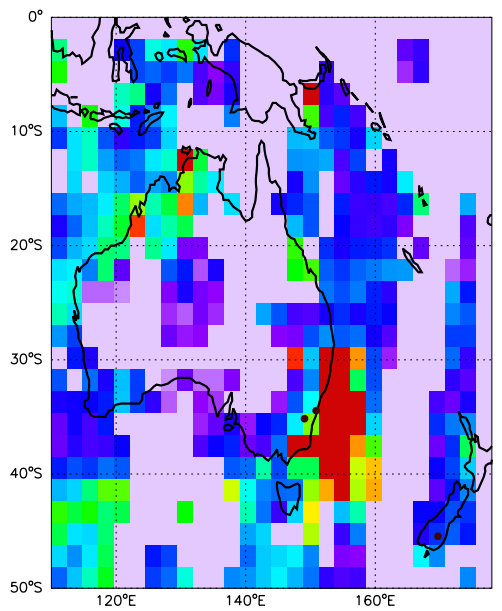

\begin{tabular}{lllll}
\hline & & 1 & \\
0.00 & 0.17 & 0.33 & 0.50 & AOD
\end{tabular}

\section{ACPD}

9, 3007-3040, 2009

2003 megafires in Australia

G. Guerova and N. Jones

Title Page

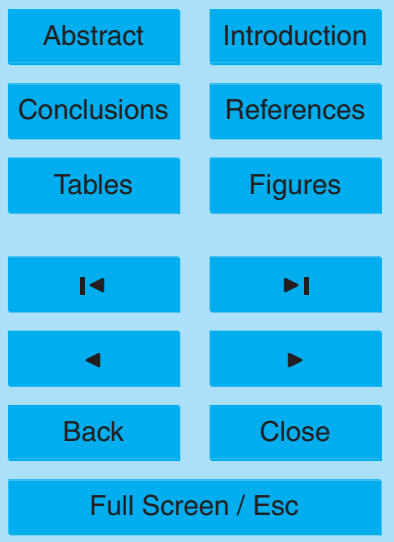

Printer-friendly Version

Interactive Discussion

Fig. 7. Episode II: (a) GEOS-Chem surface $\mathrm{O}_{3}$ (colour map) with EPA observations (coloured dots) on 17 January 2003. (b) GEOS-Chem surface wind. (c) and (d) GEOS-Chem and MODIS AODs: 17 January 2003. 


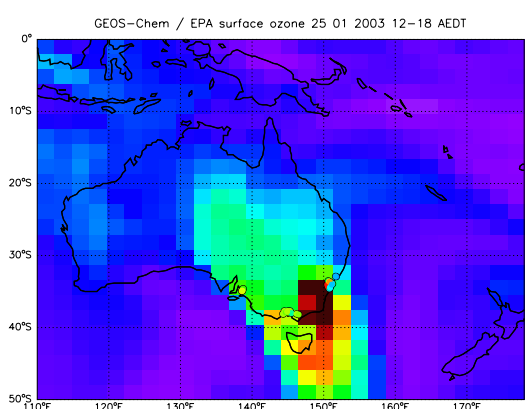

a.)

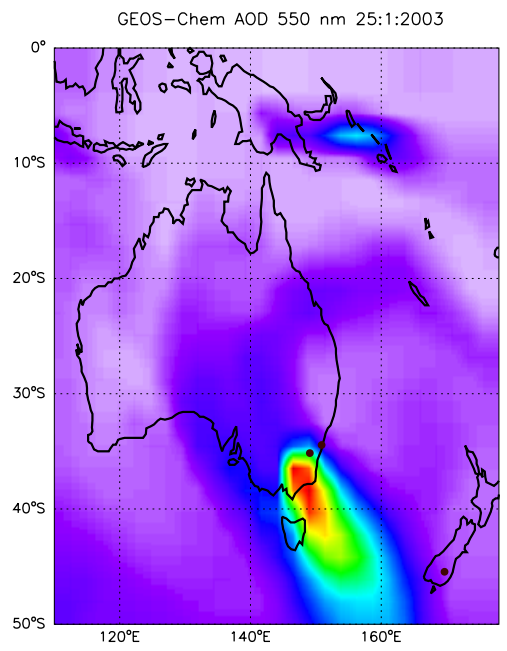

c.)

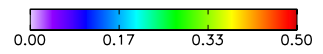

b.)

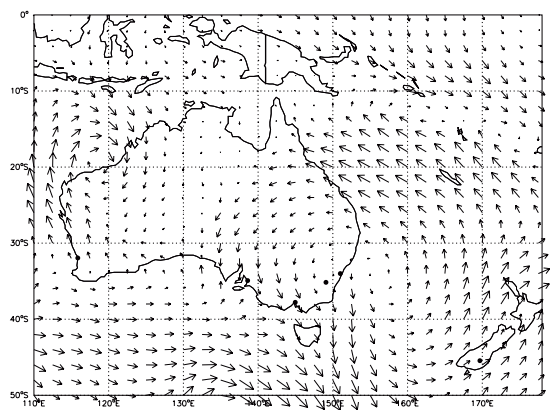

MODIS AQUA\&TERRA AOD 25:1:2003

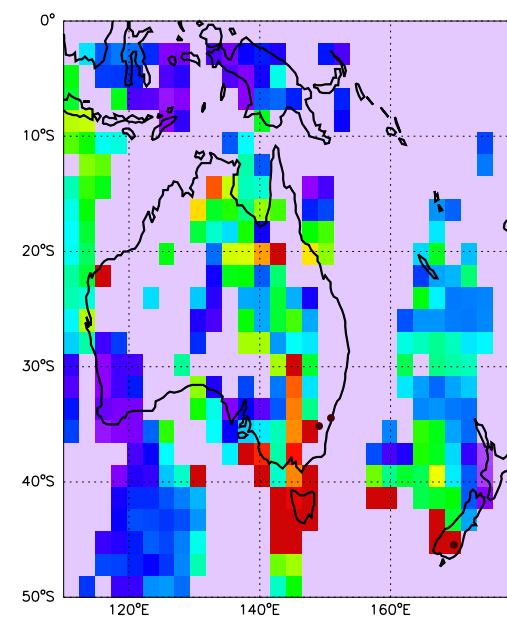

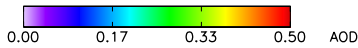

\section{ACPD}

9, 3007-3040, 2009

2003 megafires in Australia

G. Guerova and N. Jones

Title Page

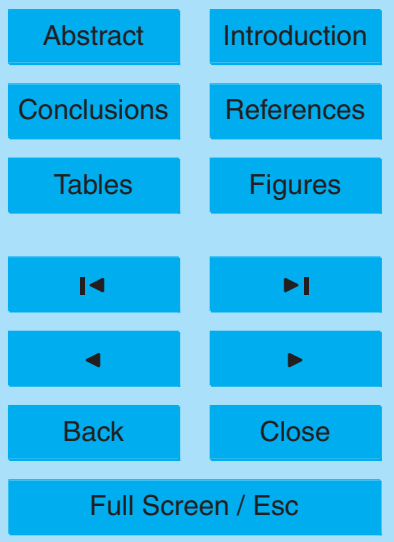

Printer-friendly Version

Interactive Discussion

Fig. 8. Episode IIIA: (a) GEOS-Chem surface $\mathrm{O}_{3}$ (colour map) with EPA observations (coloured dots) on 25 January 2003. (b) GEOS-Chem surface wind. (c) and (d) GEOS-Chem and MODIS AODs: 25 January 2003. 


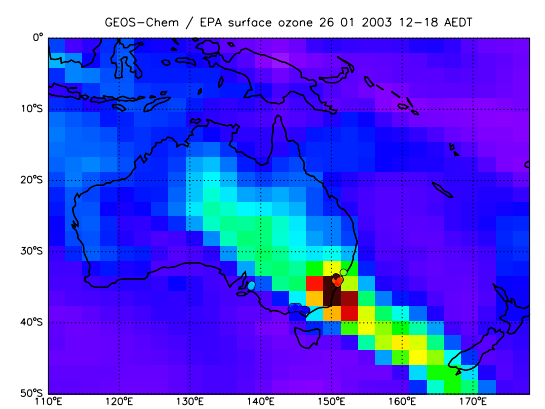

a.)

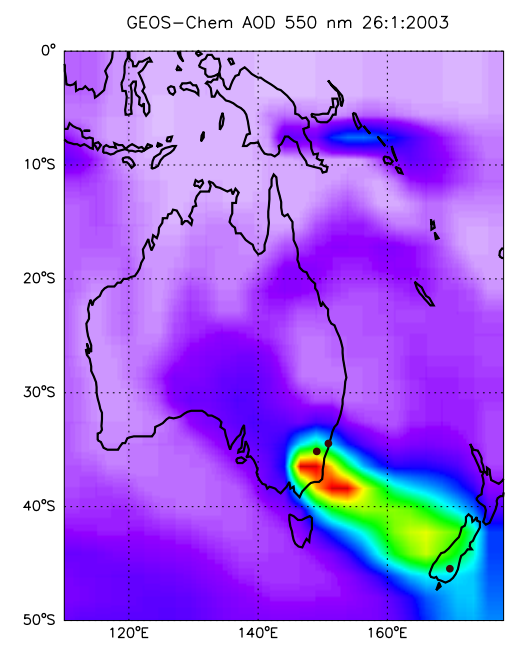

C.)

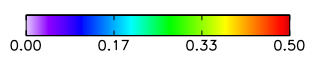

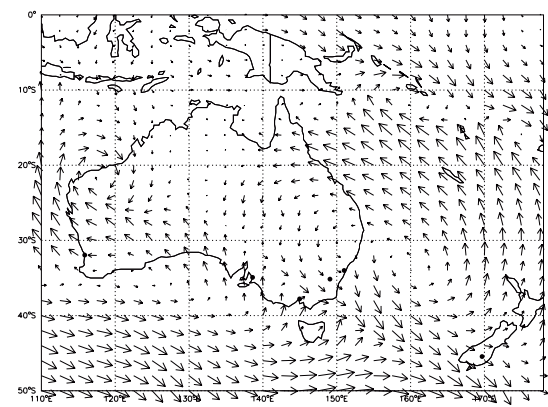

b.)

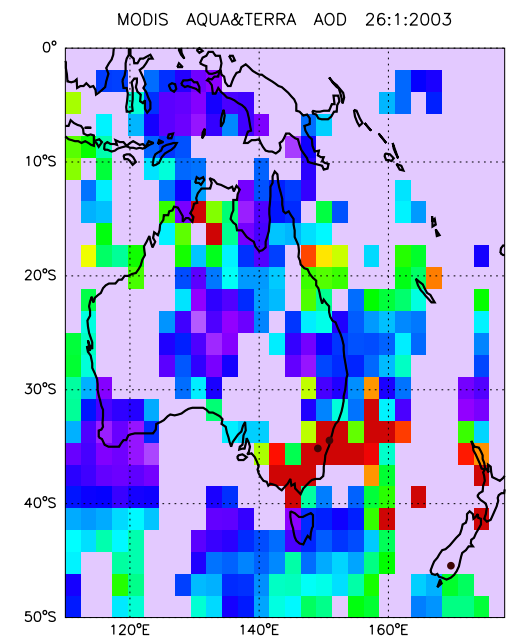

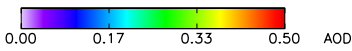

\section{ACPD}

9, 3007-3040, 2009

2003 megafires in Australia

G. Guerova and N. Jones

Title Page

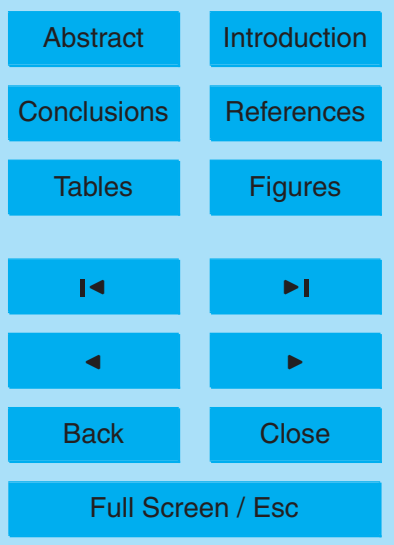

Printer-friendly Version

Interactive Discussion

Fig. 9. Episode IIIB: (a) GEOS-Chem surface $\mathrm{O}_{3}$ (colour map) with EPA observations (coloured dots) on 26 January 2003. (b) GEOS-Chem surface wind. (c) and (d) GEOS-Chem and MODIS AODs: 26 January 2003. 


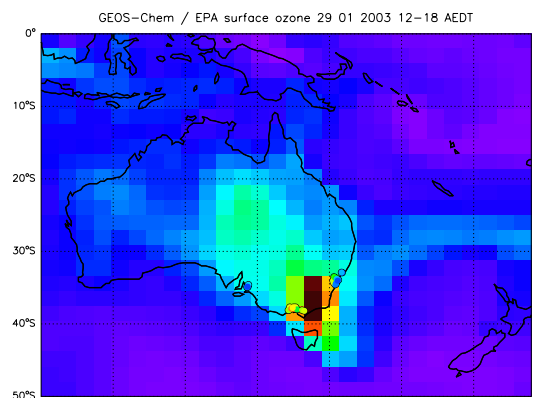

a.)

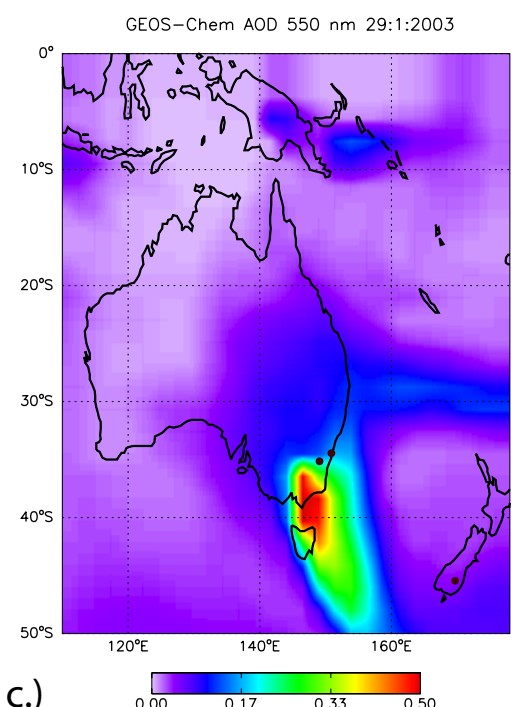

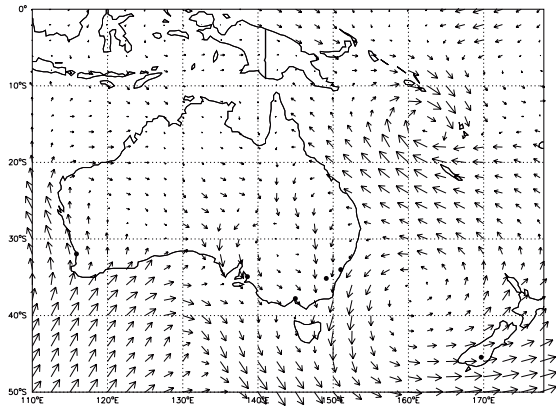

b.)

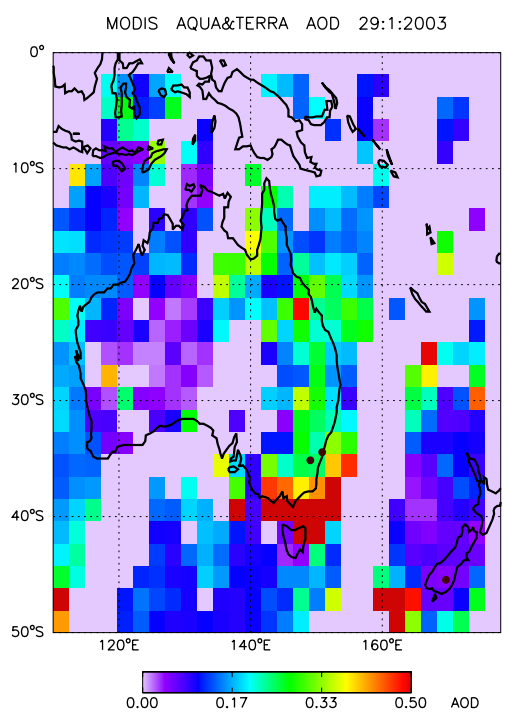

ACPD

9, 3007-3040, 2009

2003 megafires in Australia

G. Guerova and N. Jones

Title Page

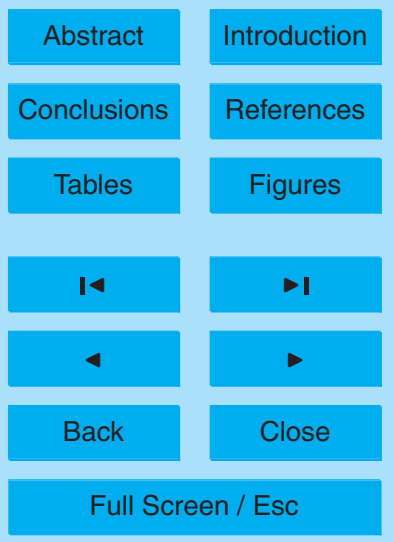

Printer-friendly Version

Interactive Discussion

Fig. 10. Episode IV: (a) GEOS-Chem surface $\mathrm{O}_{3}$ (colour map) with EPA observations (coloured dots) on 29 January 2003. (b) GEOS-Chem surface wind. (c) and (d) GEOS-Chem and MODIS AODs: 29 January 2003. 